\title{
Diagenesis and petrophysical characteristics of the shallow Pliocene sandstone reservoirs in the Shinfas Gas Field, onshore Nile Delta, Egypt
}

\author{
Mahmoud Leila $^{1} \cdot$ Ahmed Mohamed $^{1}$
}

Received: 16 October 2019 / Accepted: 25 March 2020 / Published online: 5 April 2020

(c) The Author(s) 2020

\begin{abstract}
The Pliocene Kafr El-Sheikh (KES) Formation in the onshore Nile Delta region hosts numerous shallow gas accumulations. These are readily detected on seismic profiles by definable direct hydrocarbon indicators (DHI). However, the presence of residual gases causes many production failures. Two shallow $(<1500 \mathrm{~m})$ pay zones were investigated in this study; both display seismic flat bright spots. The shallower pay zone (pay zone 1) comprises prograding distributary channel-fill sandstones, whereas the deeper pay zone 2 constitutes the transgressive distal sand bars. Pay zone 1 sandstones have better reservoir quality in terms of porosity (Av. 25.68\%), permeability $(86 \mathrm{md})$, water saturation (Av. 43.26\%), and hence host thick gas accumulation $(\sim 15 \mathrm{~m})$ with high net/gross $(\mathrm{N} / \mathrm{G})$ ratio $\sim 0.98$. On the other hand, pay zone 2 has a significant reservoir heterogeneity and contains only residual gases with N/G ratio of 0.26 . The eodiagenetic infiltration of clays (Av. 31.46\%), authigenic precipitation of glauconite (Av. 7\%), and formation of pseudomatrix materials (Av. 2\%) in pay zone 2 sandstones have the most detrimental impact on their reservoir quality. Elevated water saturation in pay zone 2 (Av. 64\%) reduced the movable hydrocarbon content and results in accumulation of residual gases. Mild mechanical compaction preserved the intergranular porosity of the pay zone 1 sandstones, and incursion of meteoric water facilitated the dissolution of feldspars, the neoformation of secondary pore spaces (Av. 2.9\%), and thus increased the reservoir storage and flow capacities. This study highlights that the initial depositional setting of the shallow siliciclastic reservoirs controls their diagenetic pathways and hence their reservoir quality.
\end{abstract}

Keywords Pliocene $\cdot$ Kafr El-Sheikh Formation $\cdot$ Nile Delta $\cdot$ Diagenesis $\cdot$ Petrophysics $\cdot$ Shallow reservoirs

\section{Introduction}

The Nile Delta was considered a minor hydrocarbon-bearing province where the exploration activities were confined to the Abu Madi valley network (Messinian) until the mid1990s. Exploring the Pliocene deep-water channel plays did not begin until the discovery of the giant offshore gas accumulations in Scarab, Saffron, and Simian fields by British Gas in 1998 and 1999 (Dolson et al. 2005). Thereafter, the exploration endeavors were mainly focused on the offshore Pliocene targets where the bulk of the Nile Delta basin resources lies in the Pliocene slope channels which form

Mahmoud Leila

Mahmoud_lotfy@mans.edu.eg

1 Geology Department, Faculty of Science, Mansoura University, Mansoura City, Egypt giant structural and stratigraphic traps (e.g., EGPC 1994; Abdel Aal et al. 1994; Kamel et al. 1998; Samuel et al. 2003; Dolson et al. 2005). On the other hand, the onshore Pliocene targets remained very poorly investigated leading to multiple uncertainties which hindered further exploration and development strategies.

In the Nile Delta onshore region (Fig. 1), the main hydrocarbon reservoirs are the Neogene-Quaternary siliciclastic successions which were deposited in a wide range of depositional environments (e.g., EGPC 1994; Dolson et al. 2005; Leila et al. 2015; Leila and Moscariello 2019). In this region, the Pliocene Kafr El-Sheikh (KES) Formation hosts the very potential shallow siliciclastic reservoirs which were deposited during and after the major marine transgression at the end of the Messinian salinity crisis (MSC) (Fig. 2) (Barber 1981; Said 1990; Garcia-Castellanos et al. 2009). The Pliocene targets host mainly biogenic gases sourced from the Pliocene shales above and below the sandstone

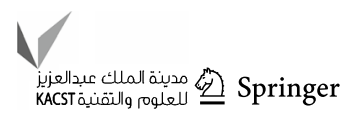



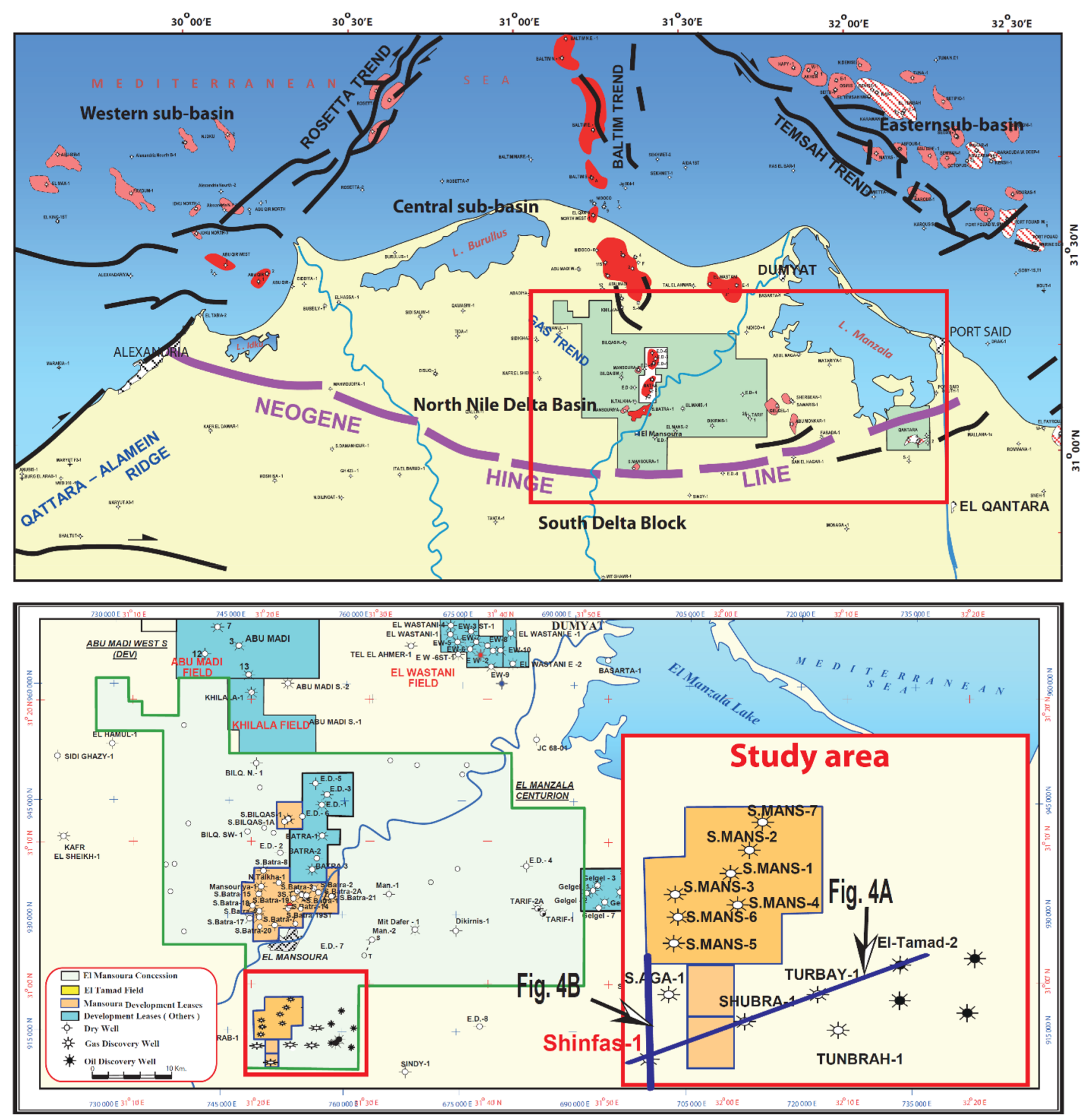

Fig. 1 Location of the study area in the Nile Delta onshore region. The studied Shinfas Field is located in the southern part of the North Nile Delta basin directly to the north of the Neogene Hinge Zone

reservoirs (Vandre et al. 2007; Leila and Moscariello 2017). The shallow Pliocene gas pay zones are characterized by very definable direct hydrocarbon indicators (DHI) in the seismic profiles (e.g., flat and bright spots) which permitted industrial success rate of approximately $90 \%$ (Samuel et al. 2003; Dolson et al. 2005). Production failures in these shallow targets are mainly resulted from the presence of residual gas and the poor quality of the reservoirs. In shallow siliciclastic reservoirs $(<2000 \mathrm{~m})$, the initial depositional conditions exercise a decisive influence over the near-surface diagenetic attributes and therefore controls their petrophysical characteristics (e.g., Kim et al. 2007; Hammer et al. 2010; Mansurbeg 2017; Leila and Moscariello 2018; Leila et al. 2019). Accordingly, understanding the link between the depositional facies and diagenetic pathways is crucial for predicting the spatiotemporal distribution of different 

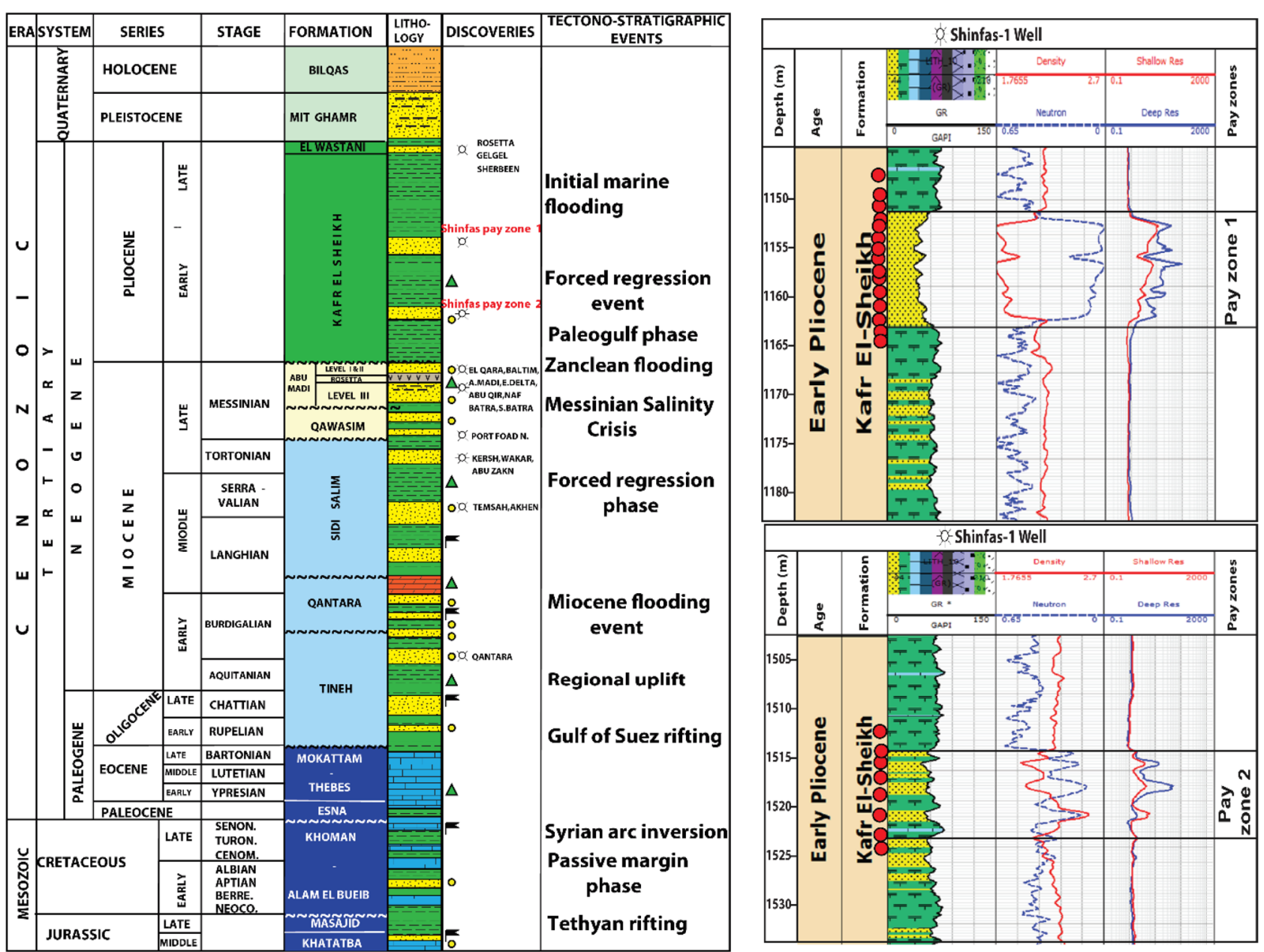

Sandstones $\square$ Limestone

$E$ Shale $\forall v v$ Evaporites

Shaly sandstone $\square$ Dolomite $O$ Reservoir Rocks $\triangle$ Seal Rocks

Source Rocks

Fig. 2 Generalized lithostratigraphic column of onshore Nile Delta region illustrating the stratigraphic setting of the potential within the Pliocene succession correlated with the studied pay zones in Shinfas-1 well [Mansoura Petroleum Company in Corex (2007)]

diagenetic attributes which strongly control the facies reservoir quality. Moreover, high-resolution definition of the reservoir facies distribution and geometry is important for reducing the exploration risks within the Pliocene succession in the Nile Delta.

\section{Geologic setting}

The Nile Delta is a passive margin basin constituting the northeastern part of the slightly deformed unstable shelf of the African continental margin (Dixon and Robertson 1984; Said 1990; Sarhan and Hemdan 1994). Continuous rifting and tectonic extension between the Afro-Arabian and Eurasian plates which commenced at Late Triassic up to Early Cretaceous developed multiple E-W trending rift basins (Mosconi et al. 1996; Loutit et al. 2001; Dolson et al. 2005). These were inverted during the Cretaceous forming the NE-SW-oriented folds of the Syrian arc series south of the Nile Delta and Eastern Mediterranean (Abd-Allah 2008). The Neogene tectono-stratigraphic evolution of the Nile Delta was controlled by the formation of the "hinge zone" (Fig. 1), which dates to the Jurassic Tethyan margin rifting and opening of the Mediterranean (Orwig 1982; Harms and Wray 1990; Kamel et al. 1998). Continuous subsidence along the hinge zone resulted in a substantial thickening of the Neogene-Quaternary sedimentary succession basinward (Ross and Uchupi 1977; Kamel et al. 1998; Sarhan and Hemdan 1994; Abdel Aal et al. 1994).

The stratigraphy of the north Nile Delta basin comprises more than $6 \mathrm{~km}$ thick of essentially siliciclastic OligoceneQuaternary sediments (Rizzini et al. 1978; Hussein and Abd-Allah 2001). These are mainly fluvial facies that were sourced from the Gulf of Suez (GOS) rift shoulders and entered the basin through the deep canyons incised during the GOS rifting and northward tilting of the Nile Delta 
during the Oligo-Miocene time (Sarhan and Hemdan 1994; Dolson et al. 2005). Major marine transgression of the Early Miocene caused the deposition of thick marine shales (Qantara and Sidi Salem formations) (Fig. 2), which host major prolific hydrocarbon source and reservoir rocks in the Nile Delta onshore and offshore regions (EGPC 1994). Commencing at approximately 6.0 Ma, the Straits of Gibraltar closed, creating a complete desiccation of the Mediterranean Sea (MSC). Subsequently, large canyons were incised around the Mediterranean peripheries, whereas widespread salt deposition occurred in the basin center (e.g., Barber et al. 1981; Palmieri et al. 1996; Dalla et al. 1997). These canyons were later infilled during the late MSC by thick fluvial-estuarine deposits "Abu Madi Formation" (Barber 1981; Said 1990; Dolson et al. 2001, 2005; Leila and Moscariello 2019). After the MSC, continuous marine transgressions overstepped the Messinian canyons and exposure areas (Said 1990; Dolson et al. 2001, 2005). These resulted in the deposition of the thick marine shales of the KES Formation which provide effective seals for the hydrocarbons trapped in the Messinian canyon-infill siliciclastics (e.g., Leila and Moscariello 2019). Another forced regression phase prevailed during late Early Pliocene (Late Zanclean 3.8 Ma), and several individual progradational sequences were developed (Dolson et al. 2005). The event is climatically induced and correlated with the global climatic changes during Late Zanclean which led to a major fall in the Mediterranean Sea level and retreat of the shoreline resulting in accumulation of fluvial and coastal sediments in the Nile Delta (e.g., Loncke et al. 2002; Zachos et al. 2001). During this phase, deltaic sedimentation prevailed in the onshore and deep-water turbidities with well-developed distal fans and slope channels characterized the offshore parts (Fig. 3). The Pliocene delta is fairly asymmetric and characterized by very rapid sedimentation of the Plio-Pleistocene sediments in the steep eastern side. The western side is more gentle and dominated by extensive slope channel systems (Fig. 3).

\section{Materials and methods}

\section{Petrographic and mineralogical analyses}

A total of 23 sidewall core samples from the sandstone pay zone intervals in Shinfas-1 well were used in this study (Fig. 2). Petrographic analyses involved a detailed examination of 23 thin sections using the conventional petrographic microscope under plane-polarized light. The thin sections

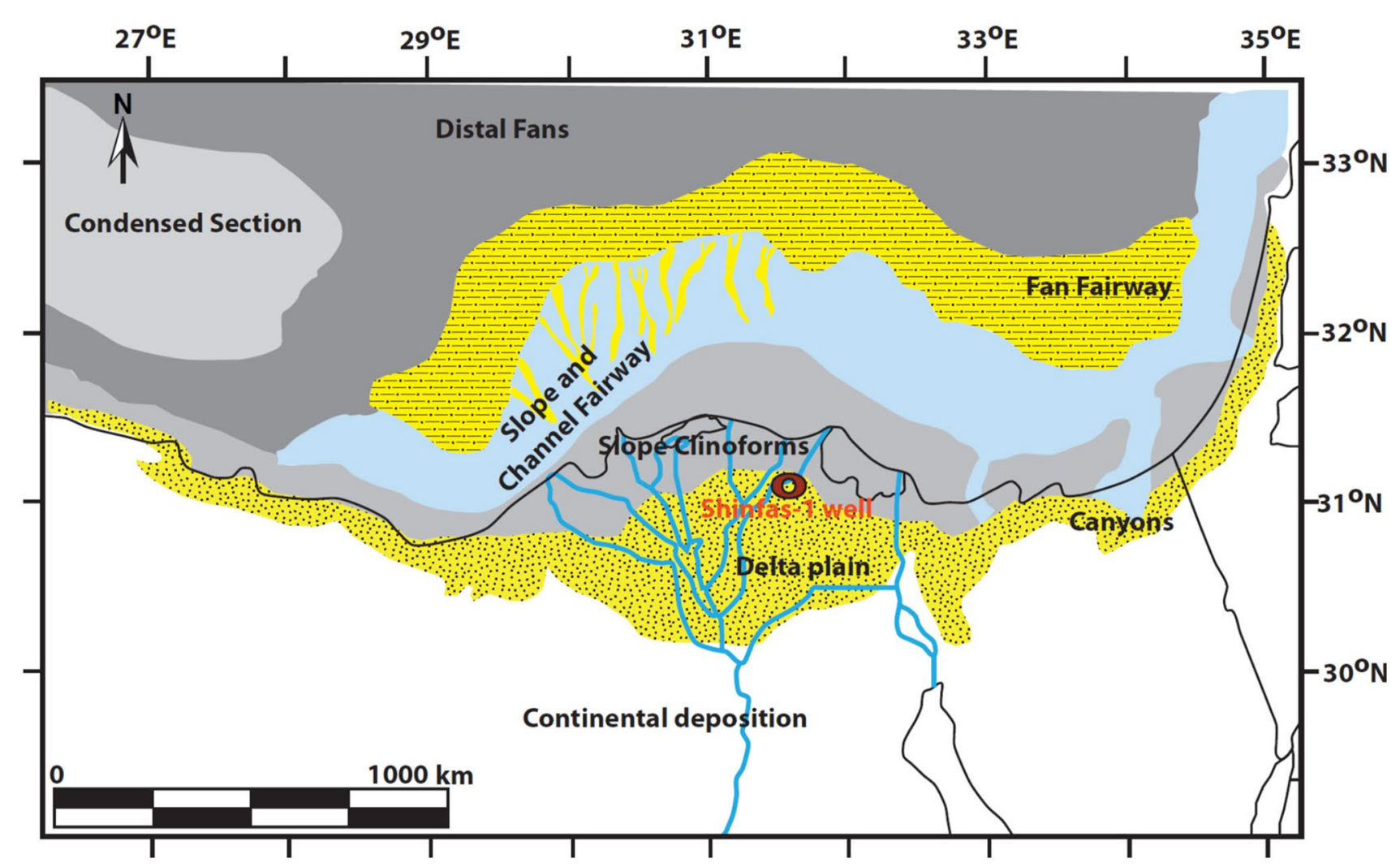

Fig. 3 Paleogeographic map illustrating the gross depositional environments at the boundary between the lower and middle Kafr El-Sheikh Formation successions (modified after Dolson et al. 2005) 
were impregnated with blue dye to recognize the porosity. To identify the different carbonate mineral phases, the thin sections were also stained with mixed Alizarin Red-S and potassium ferricyanide solutions. Sodium cobalt nitrate solution was utilized to identify the feldspar minerals. The mineralogical modal compositions were obtained using pointcounting technique (Gazzi 1966; Dickinson 1970). Scanning electron microscopy (SEM) was performed on the selected samples at Corex laboratories, Egypt, to provide insights on the morphology, origin, and composition of the different pore-occluding cements. The samples were mounted on standard aluminum stubs and then coated with gold prior to the SEM analysis.

\section{Burial history}

1D burial and thermal history diagram was constructed for the studied Shinfas-1 well using PetroMod Express (version 15) software to identify the paragenetic sequence of the different authigenic mineral phases. A constant heat flow of $60 \mathrm{~mW} / \mathrm{m}^{2}$ and geothermal gradient of $2.3{ }^{\circ} \mathrm{C} / 100 \mathrm{~m}$ were applied in this study (Riad et al. 1989; Shaaban et al. 2006). The thermal model was calibrated using the measured bottom-hole temperature (BHT) values.

\section{Petrophysical analysis}

Routine core analyses which comprise permeability, porosity, grain density, and water saturation measurements were carried out at Corex laboratories, Egypt. The measurements were taken on a total of 11 sidewall core plugs from the studied Pliocene pay zones. Nitrogen permeameter and helium gas expansion porosimeter were utilized for porosity and permeability measurements. The content of water saturation was also measured following the Dean Stark distillation-extraction technique (Dean and Stark 1920). Complete wireline log suite (gamma ray, shallow and deep resistivity, sonic, neutron, and density logs) was interpreted using Schlumberger Techlog 2015 software in order to measure the different petrophysical parameters of the studied pay zone intervals.

\section{Results}

\section{Pliocene seismic stratigraphy}

In the study area, the Pliocene succession comprises the post-MSC facies overlying the Messinian erosion surfaces (Fig. 4a). The Pliocene succession consists of well-bedded, continuous, parallel, vertically variable amplitude, and frequency reflectors (Fig. 4a, b). Two intra-Pliocene sequence boundaries subdivided the KES Formation into three successions (lower, middle, and upper) (Fig. 4). The lower sequence boundary comprises a continuous, high-amplitude, and undulated seismic reflector separating the lower and middle KES successions. The upper sequence boundary constitutes a continuous, moderate-amplitude, and slightly undulated seismic reflector separating middle and upper KES successions. The lower sequence boundary documents the Late Zanclean ( 3.8 Ma) forced regression phase which marked the end of the Zanclean marine flooding in the entire Mediterranean basin (e.g., Dolson et al. 2005). This boundary marks the end of the deep marine paleogulf phase and transition into the fluvio-deltaic sedimentation (e.g., Sallam et al. 2018). On the other hand, the upper sequence boundary presents the late Early Piaceanzean $(\sim 3.6 \mathrm{Ma})$ transgression which marked a restoration of the marine conditions in the Nile Delta; nevertheless, the sea level was comparatively lower much lower than the marine paleogulf phase (e.g., Loncke et al. 2002; Samuel et al. 2003; Dolson et al. 2005; Sallam et al. 2018).

The lower KES succession has a thickness ranging from 300 (milliseconds ms) to $600 \mathrm{~ms}$, and its thickness locally increases in the southwestward direction (Fig. 4a). It consists of parallel, semi-transparent, low-amplitude, and semichaotic reflectors changing upward into parallel, high-amplitude, and continuous reflections (Fig. 4a, b). The chaotic, semi-transparent seismic facies at the base of the succession likely represent the syn-Zanclean open marine facies that were accumulated directly after the end of the MSC along the entire Mediterranean (e.g., Clauzon et al. 1995; Lofi et al. 2005). The upward increase in seismic amplitude and continuity suggests a prograditional depositional conditions with a marked transition from open marine to relatively shallower facies. This is further confirmed by the upward decrease in gamma ray values and the abundant sandy facies at the upper part of the lower KES (Fig. 4a, b). The middle KES succession has a uniform thickness ranging from 250 to $300 \mathrm{~ms}$ of parallel, continuous, and high-amplitude seismic reflections (Fig. 4a). This succession is mostly dominated by progradational deltaic facies which were accumulated after the Late Zanclean forced regression phase (e.g., Dolson et al. 2005).

The lower pay zone (pay zone 2) comprises the upper part of the lower KES succession. It consists of flat, parallel, and high-amplitude seismic reflections that are stacked forming remarkable bright spots (Fig. 4a, b). The thickness of the bright spots is approximately $25 \mathrm{~ms}$ and extends laterally for almost $1 \mathrm{~km}$ in the N-S direction (Fig. 4b). This pay zone displays a serrated gamma ray log curve (Fig. 2), and it consists mainly of fine-grained laminated and slightly bioturbated sandstones interbedded with siltstones and mudstones. These facies represent the distal sand bar deposits accumulated prior to the Late Zanclean forced regression phase (e.g., Samuel et al. 2003; Dolson et al. 2005). The

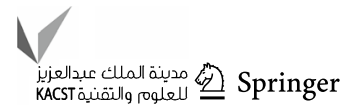



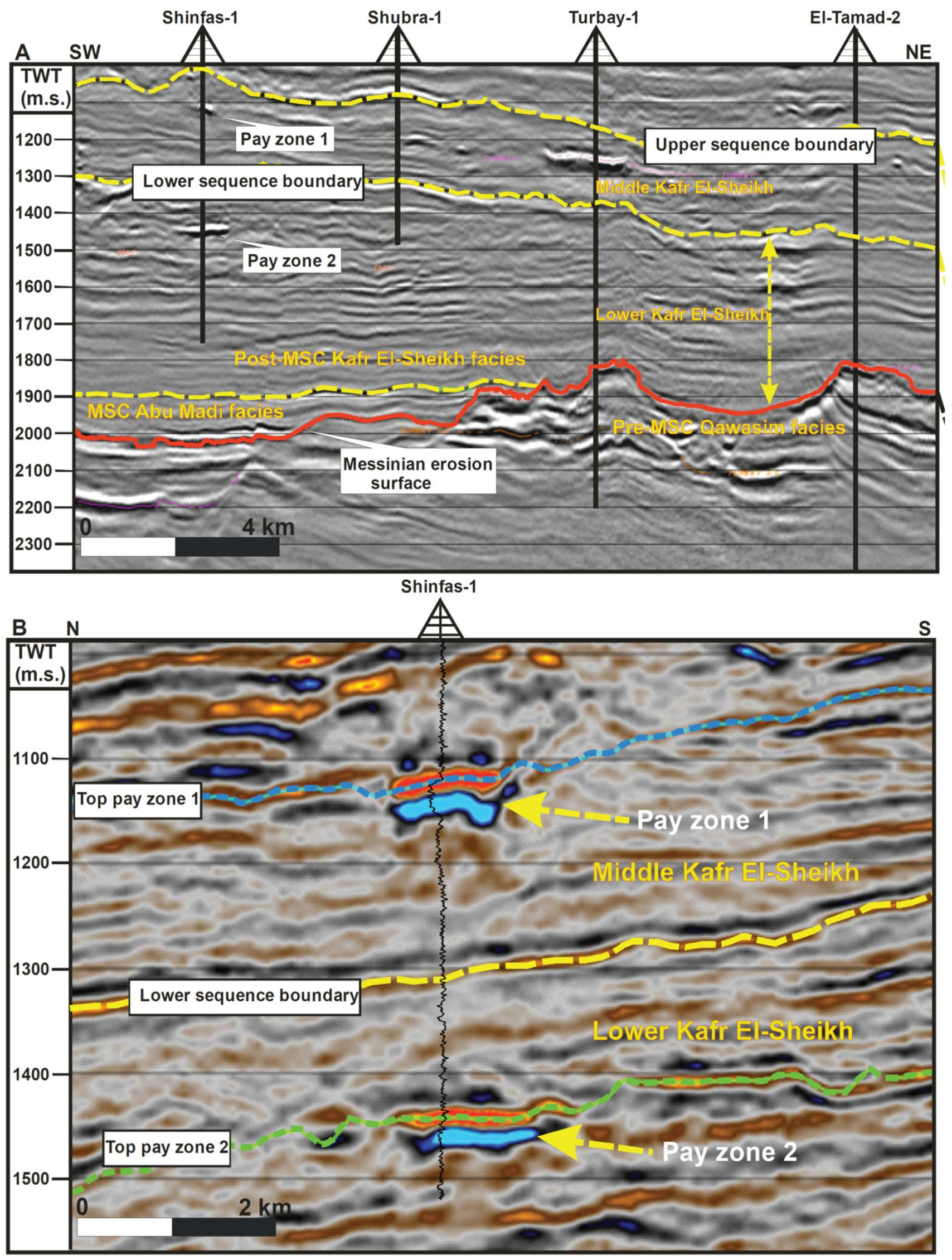
४Fig. 4 Interpreted seismic profiles illustrating the seismic characteristics of the studied pay zone intervals in the study area (see locations in Fig. 1). Both pay zones are represented by anomalously highamplitude, flat reflections

sandstones are distributed in high-amplitude $\mathrm{N}-\mathrm{S}$-oriented, isolated sand bars which vary in width from 400 to $100 \mathrm{~m}$ (Fig. 5b).

The upper pay zone (pay zone 1) consists of approximately 40-ms-thick, high-amplitude, parallel, and flat seismic reflectors in the upper part of the middle KES succession (Fig. 4a, b). These reflectors comprise two remarkable bright spots which extends laterally over $750 \mathrm{~m}$ in the N-S direction (Fig. 4b). Pay zone 1 displays a cylindrical gamma ray $\log$ curve with a very sharp top and base (Fig. 2). It consists of coarse-grained, massive, and faintly crossbedded sandstones. These represent the deltaic distributary channel-fill facies which constitute a part of the prograditional sequences developed after the Late Zanclean forced regression phase (e.g., Dolson et al. 2005). These channels were defined on the extracted RMS-amplitude map and are characterized by thin $(\sim 350 \mathrm{~m})$, ribbon-shaped high-amplitude bodies oriented in the NW-SE and NE-SW directions (Fig. 5a). High-amplitude, lenticular-shaped bodies in front of the distributary channel mouths likely represent the distributary mouth bar facies which could serve as potential targets for further exploration in the study area (Fig. 5a).

\section{Detrital composition of the Pliocene pay zones}

The detrital composition of the studied Pliocene pay zones is quite similar (Fig. 6). They contain abundant quartz and feldspars with traces of lithic fragments, which permits their classification as subarkose arenite and arkosic wacke sandstones (Fig. 6). Pay zone 1 has an average QFL composition ranging from $\mathrm{Q}_{85} \mathrm{~F}_{13} \mathrm{~L}_{2}$ to $\mathrm{Q}_{83} \mathrm{~F}_{14} \mathrm{~L}_{3}$ for the arenite and wacke sandstones, respectively. On the other hand, pay zone 2 has comparatively lower quartz and higher lithic contents with an average QFL composition of $\mathrm{Q}_{83} \mathrm{~F}_{13} \mathrm{~L}_{4}$ and $\mathrm{Q}_{75} \mathrm{~F}_{19} \mathrm{~L}_{6}$ for the arenite and wacke samples, respectively. In order of decreasing abundance, the major detrital components in the pay zone 1 sandstones are quartz (Av. 47.78\%), clay matrix (Av. 20.76\%), feldspars (Av. 7.48\%), glauconite (Av. 2.48\%), lithic fragments (Av. 1.43\%), and mica (Av. 1.29\%). In pay zone 2, they are quartz (Av. 38.54\%), clay matrix (Av. 31.46\%), feldspars (Av. 7\%), glauconite (Av. 4\%), mica (Av. $2.06 \%$ ), and lithic fragments (Av. 2.01\%).

Pay zone 1 sandstones are dominated by poorly sorted, very fine to coarse-grained quartz grains (Fig. 7a, b). Feldspars consist mainly of K-feldspars with only minor traces of plagioclase (Fig. 7c). Feldspars are partly to completely altered and dissolved (Fig. 7c). Argillaceous matrix components are relatively rare and only present in small patches
(Fig. 7b). Clay matrix occasionally forms thin coatings around the detrital quartz and feldspar grains (Fig. 7c). Mica is present as thin, fibrous muscovite, and platy biotite crystals which are partly altered (Fig. 7a). Detrital glauconite pellets are also present in minor quantities (Fig. 7a).

The pay zone 2 sandstones contain abundant fine and medium-grained, moderately sorted quartz grains (Fig. 7d-f). The feldspars are dominated by K-feldspars that are comparatively better preserved than in the pay zone 1 samples (Fig. 7d, e). Lithic fragments are more abundant and consist mainly of igneous granitic components (Fig. 7d). The clay matrix is present as massive aggregates in the intergranular pore spaces and clay lamina that are oriented parallel to the detrital grain surfaces (Fig. 7e, f). Mica is mainly represented by partly to completely altered biotite which is commonly compacted between the rigid detrital framework grains to form pseudomatrix (Fig. 7e, f). Detrital spheroidal and ovoidal glauconite pellets are abundant in pay zone 2 sandstones (Fig. 7e, f). Glauconite pellets were also compacted between the rigid detrital framework increasing the pseudomatrix content in pay zone 2 sandstones (Fig. $7 \mathrm{~d}-\mathrm{f}$ ). Glauconite grains are often present in different maturity colors ranging from immature nascent pale green (Fig. 7e) to mature brown components (Fig. 7e, f).

\section{Authigenic composition of the Pliocene pay zones}

Authigenic components are very rare in the studied Pliocene sandstones (Fig. 7). In pay zone 1, the authigenic modifications comprise the pervasive dissolution of the unstable fragments (feldspars, mica) and formation of secondary intragranular pore spaces (Fig. 7a, b). The other recorded authigenic phase in pay zone 1 sandstone is the illite/smectite $(\mathrm{I} / \mathrm{Sm})$ clays which were redistributed in the form of thin coatings around the detrital framework grains (Fig. 8a, b). The I/Sm clay coats comprise short, very thin filaments which are mainly oriented parallel to the detrital grain surface (Fig. 8a). I/Sm filaments are occasionally present in the secondary pore spaces and are typically accumulated around the pore edges (Fig. 8b).

Pay zone 2 sandstones contain more abundant and diverse authigenic phases. Authigenic glauconite is only present in pay zone 2 sandstones (Av. 7\%) and comprise pore-filling and grain-replacive components (Fig. 7e, f). It is more common in the wacke samples (Av. 9.24\%). Authigenic glauconite commonly precipitates in the pore spaces in association with the infiltrated clay materials (Fig. 7e, f). Pore-filling glauconite commonly has a nascent, pale-green color indicating its homogeneous chemical maturity (low K content) (e.g., Odin and Matter 1981; Amorosi 1995). Quartz overgrowth presents a minor authigenic phase (Av. 0.6\%) that occurs only in pay zone 2 sandstones (Figs. 7d, 8d). It occurs as a distinct dust rims around the quartz grains and is more

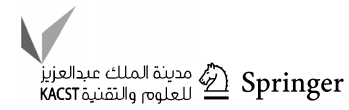


Fig. 5 Extracted RMS-amplitude maps showing the presence of channelized high-amplitude features in pay zone 1 (a) and restricted bars in pay zone 2 (b)

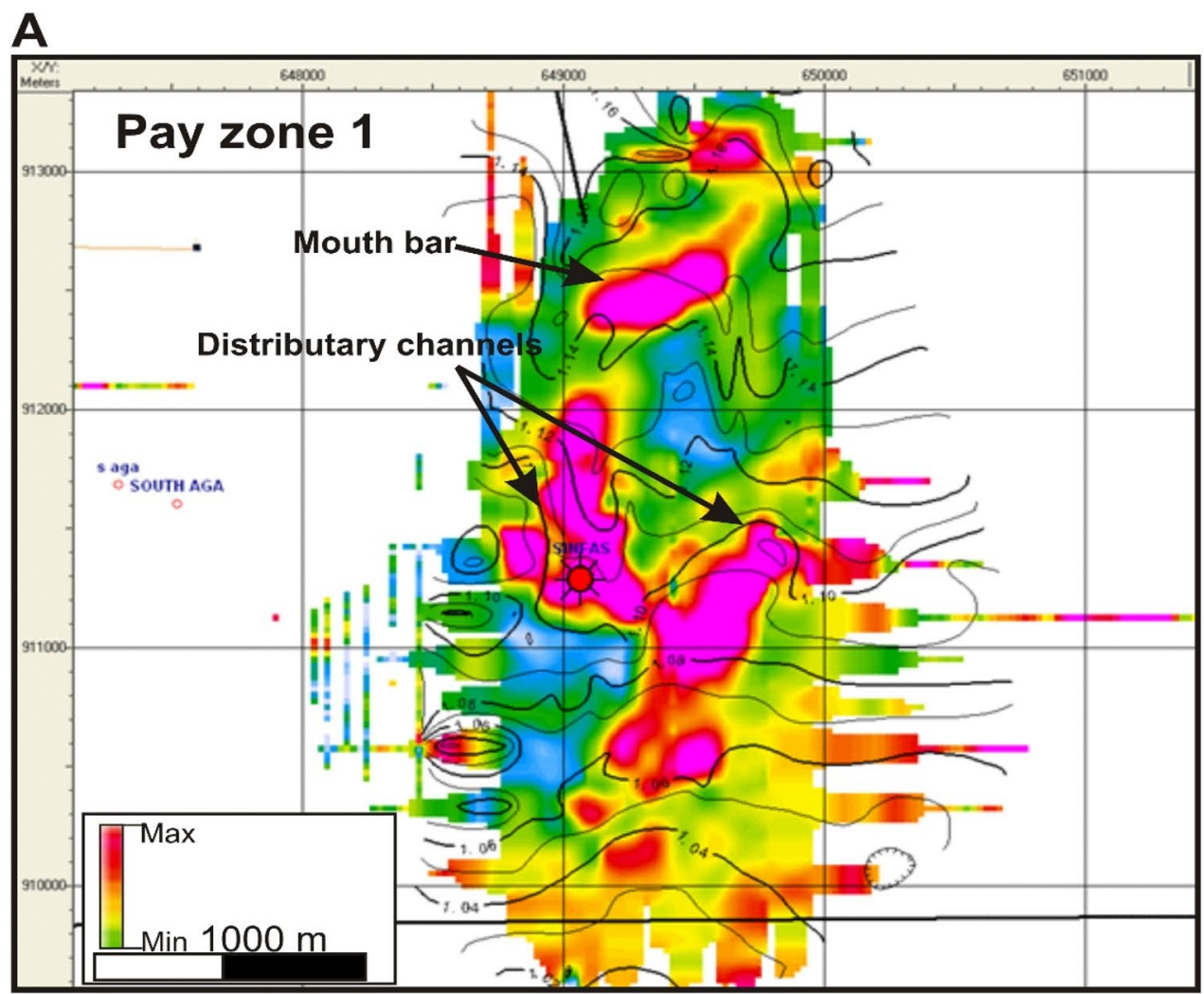

B

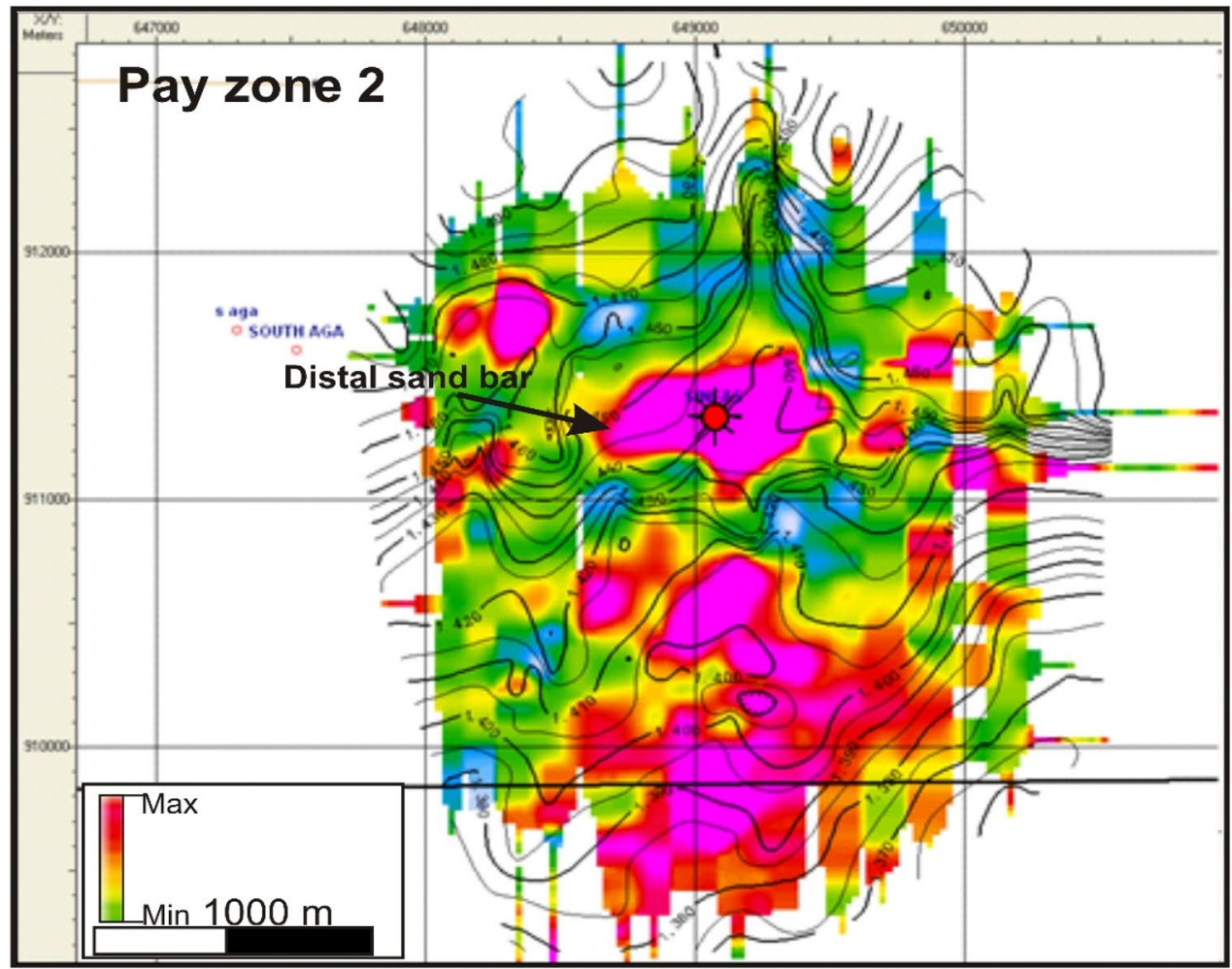

common in the arenite samples with abundant concavo-convex grain contacts (Fig. 7d). I/Sm grain coatings are also abundant authigenic phase in the pay zone 2 sandstones.
They occur as thin flakes are arranged in edge-to-edge and edge-to-face contacts forming cornflake microstructures (Fig. 8c). 


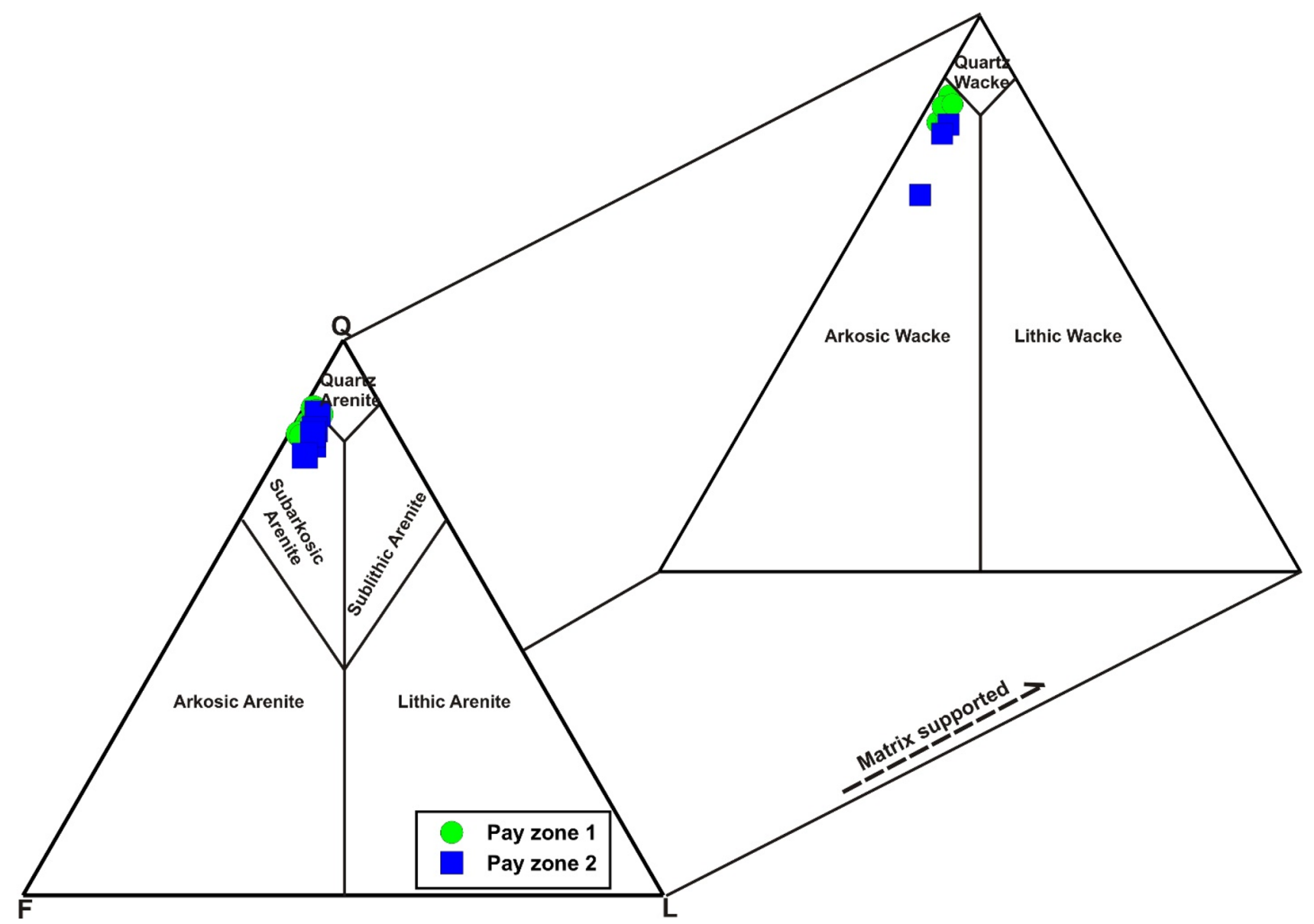

Fig. 6 Classification of the studied Pliocene sandstones composition using the QFL plot of Blatt and Tracy (1996)

\section{Petrophysical characteristics of the Pliocene pay zones}

The studied sandstones contain both primary intergranular and secondary intragranular pore spaces (Fig. 7). Primary porosity is higher in pay zone 1 (Av. 16\%) than in pay zone 2 (Av. 6.5\%) sandstones. Similarly, the secondary porosity is also more common in the pay zone 1 than in pay zone 2 sandstones (Av. 3\% and $0.75 \%$, respectively). The measured helium porosity values are also higher in the pay zone 1 (Av. 25.6\%) than in pay zone 2 sandstones (Av. $21 \%)$. Pay zone 1 sandstones have also elevated nitrogen permeability values (Av. 85 millidarcy $\mathrm{md}$ ) than pay zone 1 samples (Av. $31 \mathrm{md}$ ). The positive correlation between the nitrogen permeability and helium porosity values (Fig. 9a) suggests a good interconnected porosity network in particular in pay zone 1 sandstones. The helium porosity-grain density cross-plot (Fig. 9b) is consistent with the petrographic observations confirming the absence of highdensity pore-filling cements (e.g., carbonate) in the studied sandstones. The high helium porosity values coincide with the clean samples (clay-poor) with grain density values similar to those of quartzose sandstones $(\sim 2.65 \mathrm{~g} /$ $\mathrm{cm}^{3}$ ) (e.g., Schön 1996). On the other hand, the samples with abundant clay matrix materials (arkosic wacke) are often characterized by comparatively lower grain density $\left(\sim 2.55 \mathrm{~g} / \mathrm{cm}^{3}\right)$ and helium porosity $(<20 \%)$ (Fig. 9b). The plot highlights the impact of sandstone composition on the reservoir quality as the quartzose samples mostly have better quality than the wacke sandstones. Similarly, the highest nitrogen permeability values are confined within clean, quartzose intervals, whereas the clay-rich wackes often have low permeability values (Fig. 9c). The permeability-grain density relationship reinforces the detrimental impact of the clay matrix materials on the sandstones permeability, in particular in clay-rich sandstones (Fig. 9c). The measured water saturation displays negative correlation with the grain density values (Fig. 9d). The quartzose, clean intervals have the lowest water saturation values and hence have a better reservoir quality. The abundance of clay in the sandstones commonly increases the irreducible water content, increases the water saturation values, and 

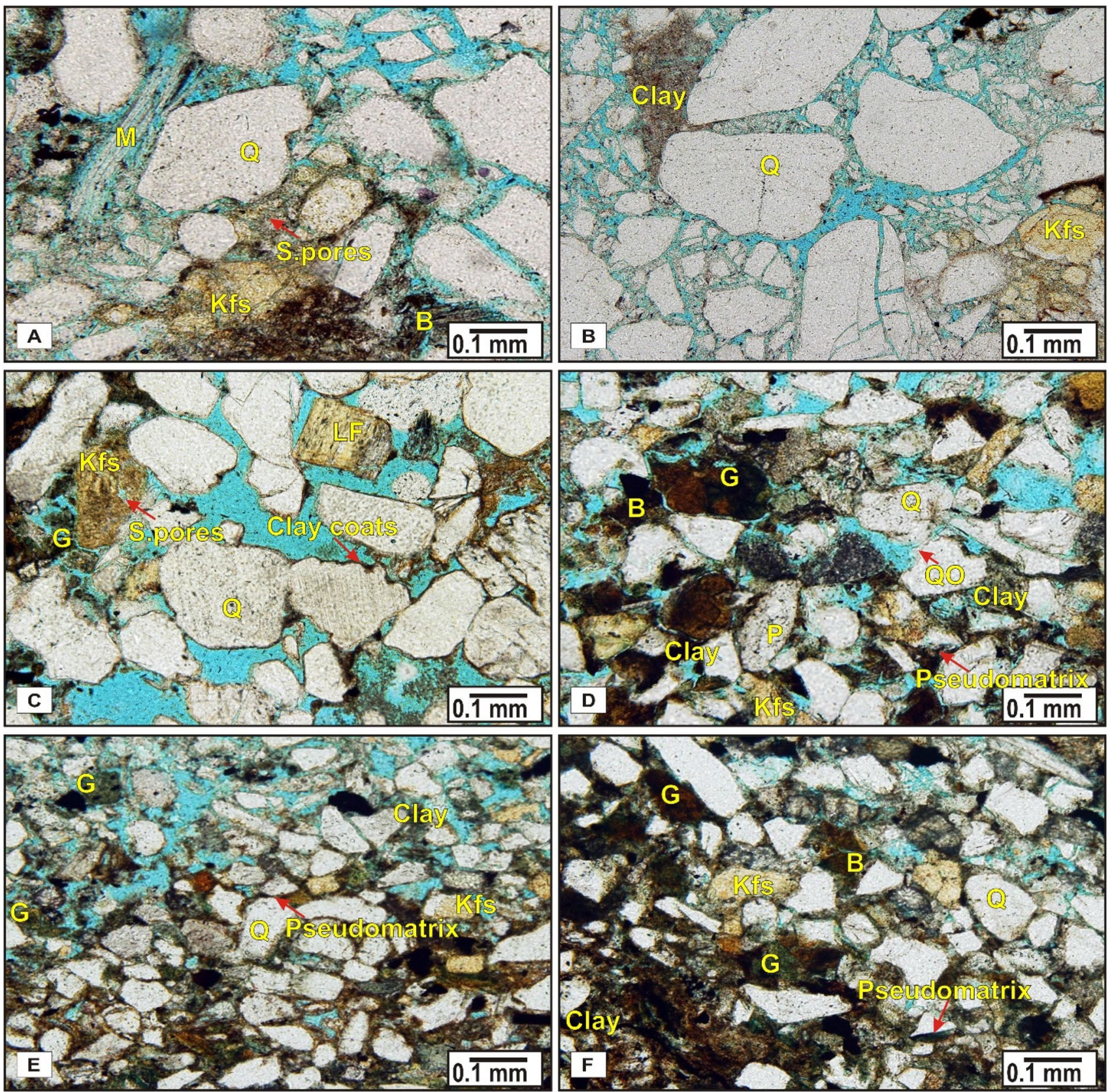

Fig. 7 Thin-section microphotographs in plane-polarized light (PPL) illustrating the petrographic composition of the pay zone $1(\mathbf{a}, \mathbf{b}, \mathbf{c})$ and pay zone 2 sandstones (d, e, f). Mineral symbols: quartz (Q),

hence decreases the hydrocarbon storage capacity (e.g., Worthington 1985).

The log-derived petrophysical parameters (porosity, permeability, shale volume, and water saturation) show similar results to the core-measured parameters (Fig. 10). The log-permeability and log-porosity values are positively correlated with the highest values recorded in the pay zone 1 sandstones (Fig. 10a). The log-porosity values display negative correlation with shale volume confirming

K-feldspar (Kfs), plagioclase (P), lithic fragments (LF), mica (M), glauconite $(\mathrm{G})$, quartz overgrowth $(\mathrm{QO})$, and secondary pores (S. Pores)

the detrimental impact of the shale volume in blocking the pore spaces and reducing the porosity values (Fig. 10b). Similarly, the log-permeability values are negatively correlated with the shale volume suggesting the presence of shale barriers which block the interconnected pore network (Fig. 10c). Only water saturation values display positive correlation with the shale volume (Fig. 10d). The water saturation-shale volume cross-plot confirms the better reservoir characteristics of the pay zone 1 sandstones which contain 1 

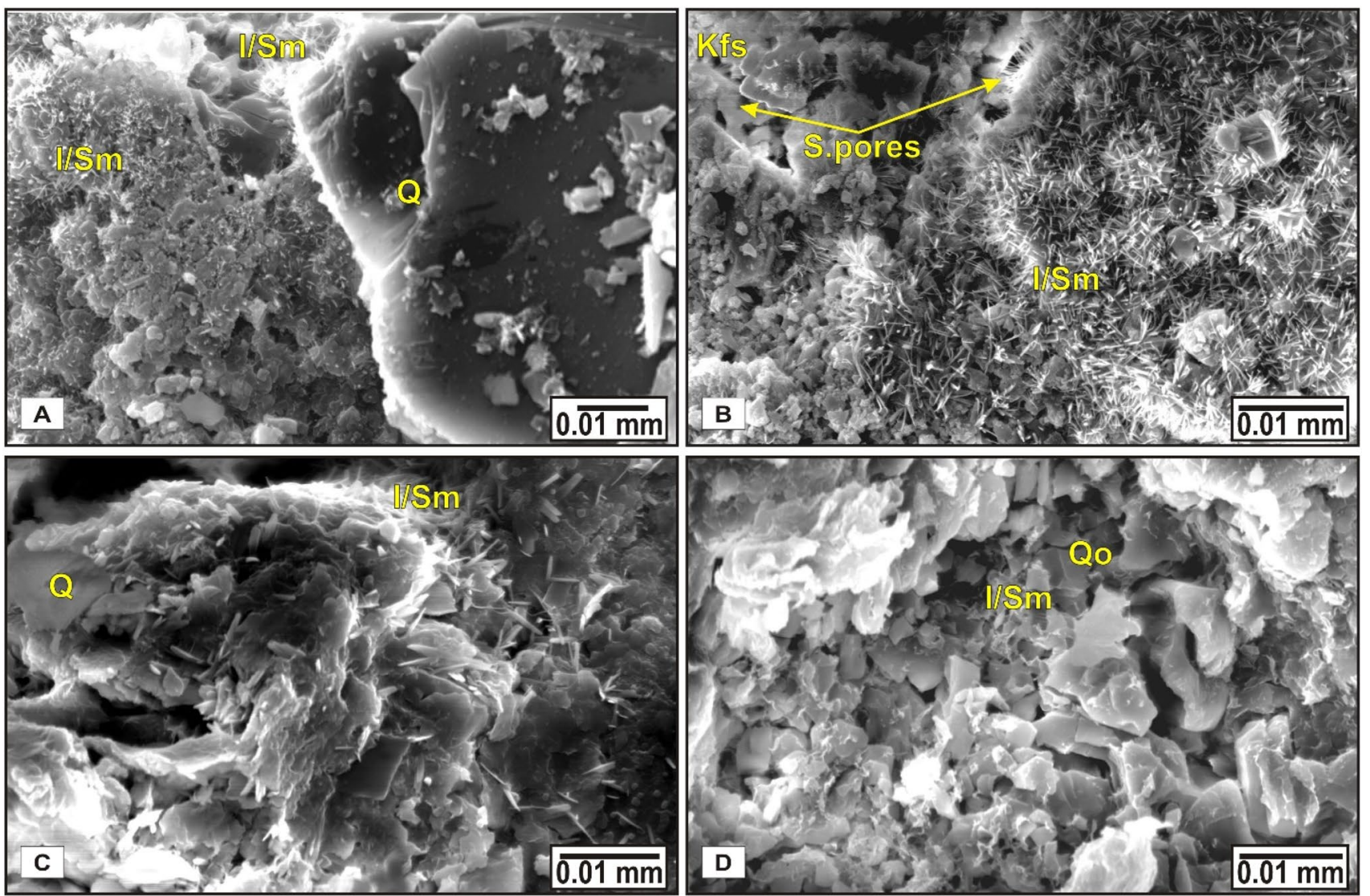

Fig. 8 SEM microphotographs illustrating the different diagenetic phases observed in the studied Pliocene pay zone 1 (a, b) and pay zone 2 (c, d) sandstones. Mineral symbols: illite/smectite (I/Sm)

the lowest content of water saturation and shale volume and have therefore high hydrocarbon storage and flow capacity (e.g., Leila and Moscariello 2019).

\section{Discussion}

\section{Depositional controls on the reservoir quality}

The studied pay zones were deposited during various phases of sea-level fluctuations (e.g., Loncke et al. 2002; Samuel et al. 2003; Dolson et al. 2005). The lower pay zone (pay zone 2) represents the transgressive distal sand bar facies accumulated during the marine paleogulf phase that prevailed subsequent to the Zanclean flooding event after the end of the MSC (Fig. 4; e.g., Sallam et al. 2018). On the other hand, the upper pay zone 1 presents a part of the prograditional deltaic facies deposited after the Late Zanclean forced regression phase (Figs. 3, 4; Dolson et al. 2005). The rapid sedimentation of the pay zone 1 sandstones in highenergy deltaic setting hindered the infiltration of substantial amounts of clays. On the other hand, pervasive infiltration of clays occurred in the transgressive pay zone 2 sandstones and resulted in near-complete deterioration of the facies intergranular primary porosity (Fig. 11a). An increase in the clay volume above $10 \%$ results in a twofold decrease in the facies intergranular porosity (Fig. 11a). Furthermore, the clay volume content more than $40 \%$ completely obliterates the facies primary intergranular porosity and hence destroys the reservoir quality (Fig. 11a). These clays are mainly present in laminated form blocking for the pore-channel network, thus reducing the hydrocarbon flow capacity and reservoir quality (Figs. 7e, f, and 11b). Moreover, the low clay content in pay zone 1 sandstones, and the absence of laminated clay barriers (Fig. 11b), resulted in a good reservoir connectivity with high net/gross $(\mathrm{N} / \mathrm{G})$ ratio $(\sim 0.98)$ (Fig. 12a). On the other hand, the abundance of laminated clay barriers in pay zone 2 sandstones induced a significant reservoir heterogeneity and hence reduced the reservoir connectivity and reservoir N/G ratio ( 0.26) (Fig. 12b).

\section{Diagenetic controls on the reservoir quality}

The studied Pliocene pay zones were subjected to very little diagenetic modifications that were frequently controlled by the initial depositional conditions (eodiagenesis). However,

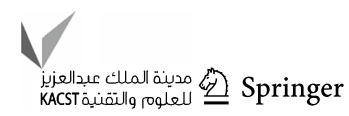


A

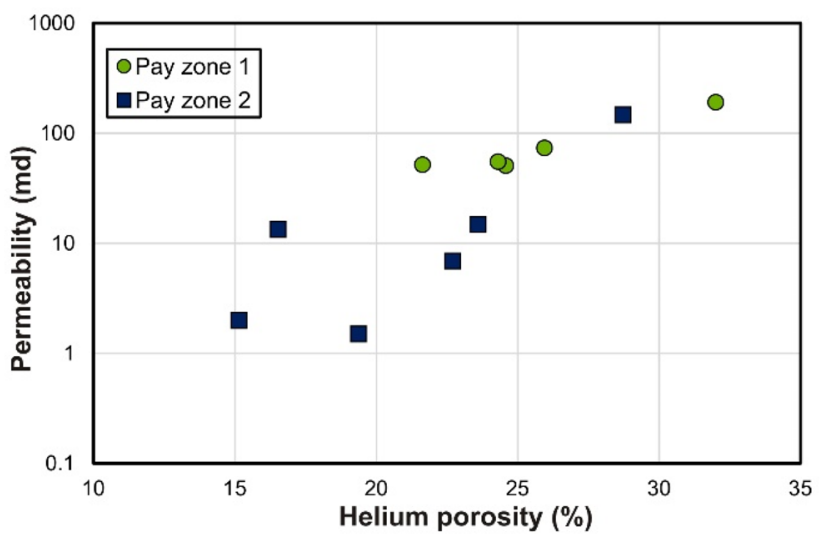

C

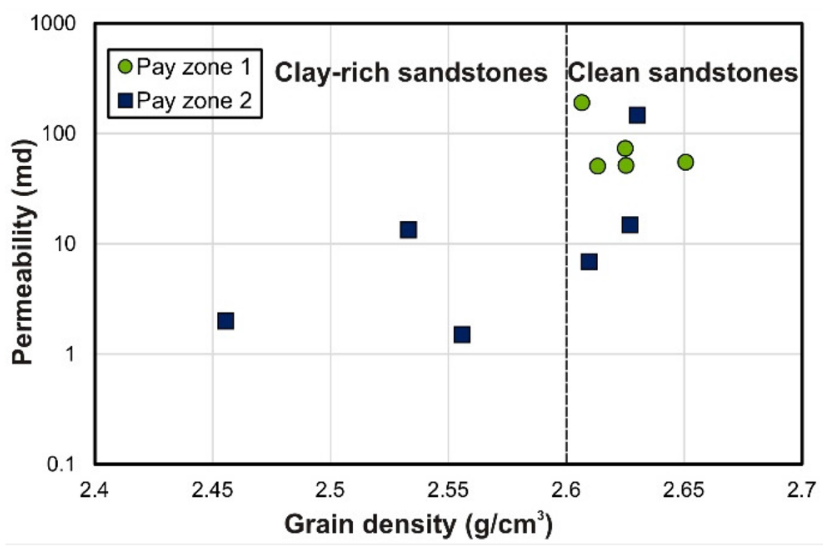

B

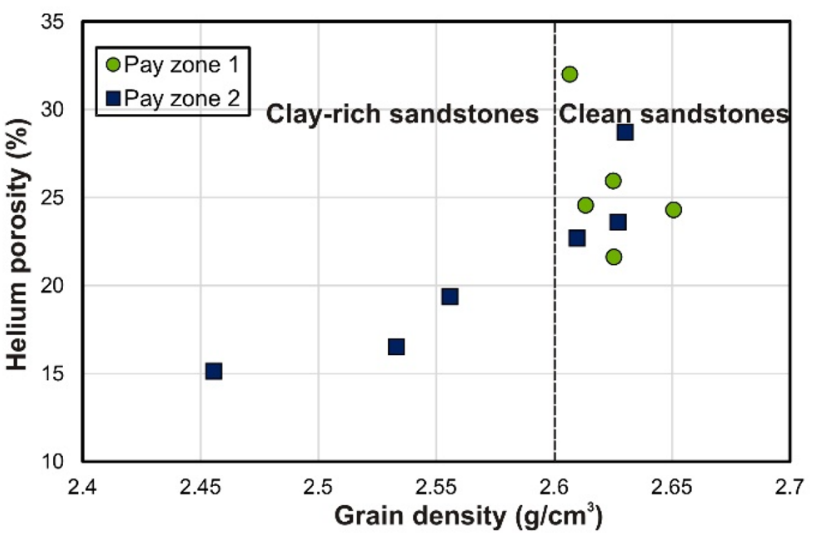

D

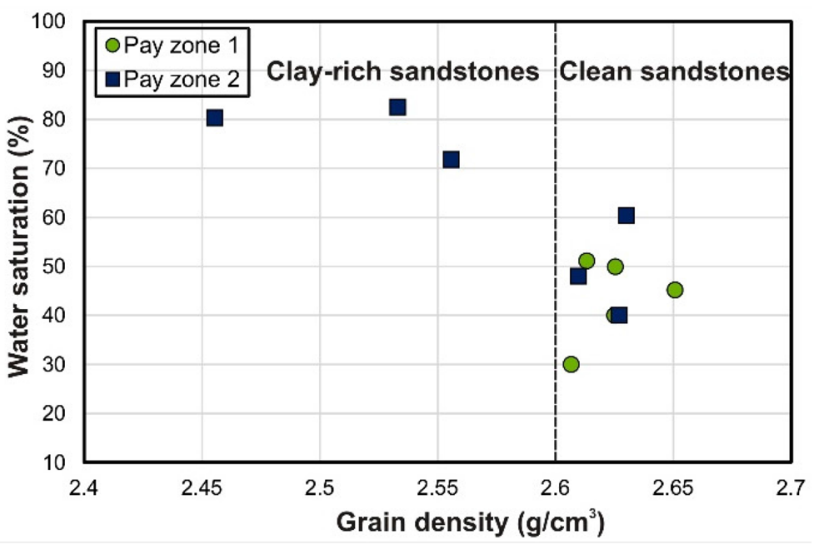

Fig. 9 Cross-plots illustrating the significant variation of the petrophysical characteristics of the studied Pliocene sandstones

both pay zone 1 and 2 sandstones experienced different diagenetic processes (Fig. 13). Significant glauconite authigenesis only characterizes the pay zone 2 sandstones (Fig. 7e, f). Glauconite precipitation preferentially occurs under suboxic to anoxic, shallow marine transgressive conditions (e.g., Odin and Matter 1981; Odin and Fullagar 1988; Michalopoulos and Aller 1995). Glauconite morphology and maturity differ significantly between the detrital and authigenic morphotypes and therefore help identify their paragenetic conditions (Amorosi and Centineo 1997). Pay zone 1 sandstones contain only detrital morphotypes which occur in different maturity, spheroid pellets (Fig. 7c). On the other hand, pore-filling flocculated, immature nascent glauconite components associated with argillaceous matrix are common in pay zone 2 sandstones. Glauconite immaturity and association with argillaceous matrix materials suggest its authigenesis very shortly after deposition through chemical precipitation and alteration of clay materials (e.g., Odin and Matter 1981; Odin and Fullagar 1988; Amorosi 1995). Glauconite maturity remained constant with depth suggesting a short duration of authigenesis $(<300 \mathrm{ka})$ based on the model of Odin and Fullagar (1988) (Fig. 13). However, the pore-filling authigenic glauconite in pay zone 2 sandstones significantly reduced its intergranular primary porosity (Fig. 14).

The abundant point grain-to-grain contacts and the presence of undeformed ductile mica flakes in pay zone 1 sandstones reflect the very mild mechanical compaction (Fig. 7a, b). On the other hand, pay zone 2 sandstones contain common concavo-convex grain-to-grain contacts suggesting more severe mechanical compaction (e.g., Lundergard 1991, Ramm 1992). This results in an overall decrease in the intergranular volume (IGV) of pay zone 2 (Av. 23\%) than pay zone 1 sandstones (Av. 36\%). Enhanced mechanical compaction in pay zone 2 sandstones also results in an increased pseudomatrix content which significantly reduced the primary intergranular porosity (Fig. 15a, e.g., Dickinson 1970). On the other hand, shallow eodiagenetic dissolution of the unstable detrital framework (e.g., feldspars) is more common in the pay zone 1 sandstones. Therefore, a more pervasive secondary porosity neoformation occurs in pay zone 1 (Av. 2.9\%) than in pay zone 2 sandstones (Av. 0.76\%). The secondary pore spaces were formed due to dissolution of mainly feldspars (Fig. 15b, e.g., Worden and Morad 2003). 
A
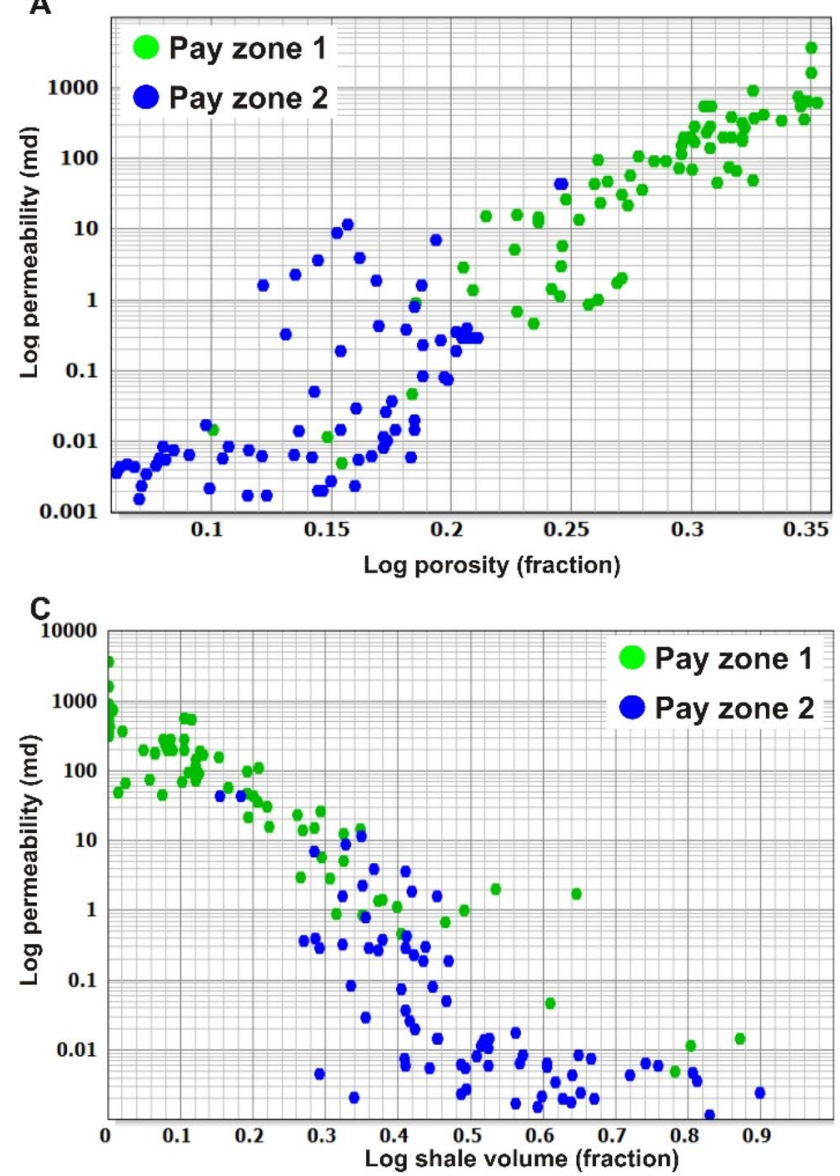

B

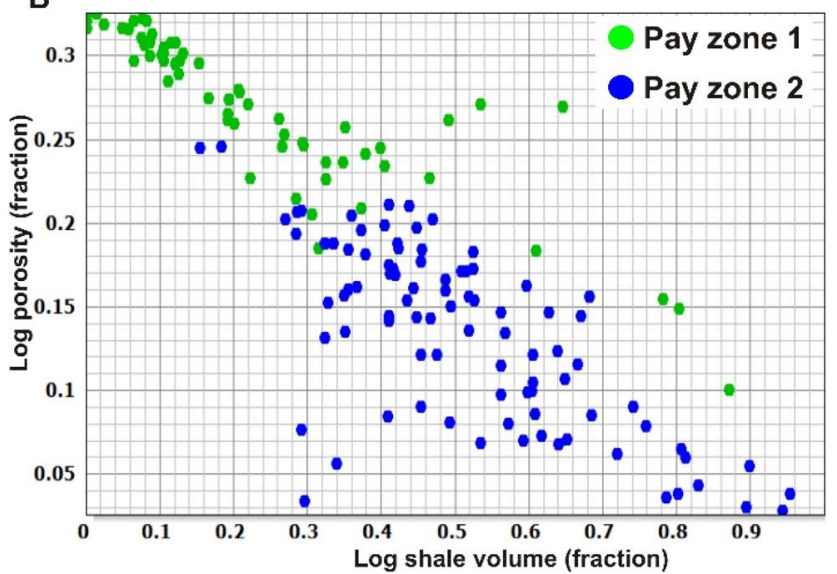

D

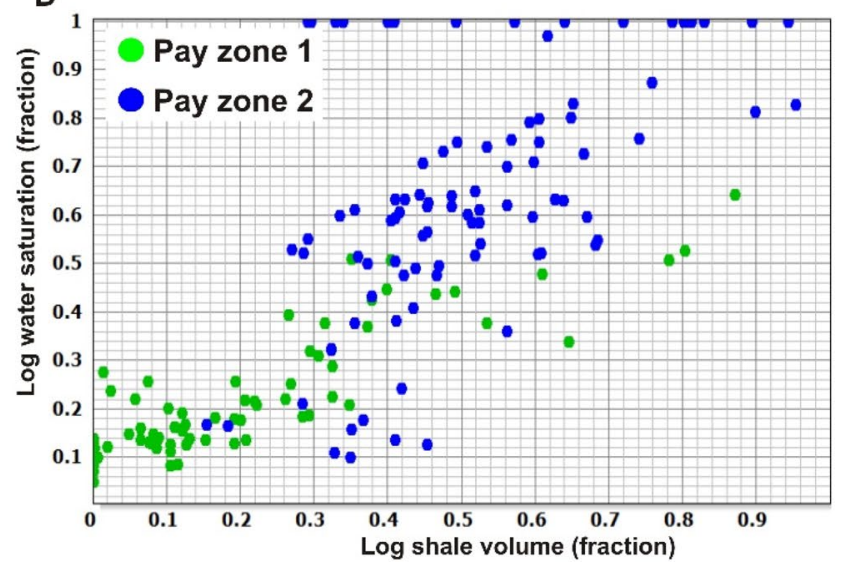

Fig. 10 Cross-plots of log-derived petrophysical parameters showing that the good reservoir sandstones are more common in pay zone 1 sandstones

The extent of dissolution on the studied pay zones is mostly controlled by their initial depositional conditions. The prograditional deltaic depositional setting characteristics of pay zone 1 sandstones permitted the eodiagenetic incursion of meteoric water and pervasive dissolution of feldspars (e.g., Morad et al. 2000; Higgs et al. 2007; Yuan et al. 2017). Moreover, the coarse-grained texture and low-matrix content of pay zone 1 sandstones facilitated the percolation of meteoric water and permitted the sediment-water interaction resulting in a more pervasive dissolution (e.g., Surdam et al. 1984; Leila et al. 2019). Evidence for shallow dissolution in pay zone 1 sandstones includes (1) the absence of associated authigenic kaolinite (e.g., Worden and Morad 2003; Leila 2019), and (2) the presence of reoriented I/Sm flakes around and inside the secondary pores edges (Fig. 8b). In pay zone 1 sandstones, dissolution occurred shortly after the deposition and lasted for approximately $500 \mathrm{ka}$ until ceased by the formation of I/Sm coatings around the detrital feldspars (Fig. 13).

Enhanced mechanical compaction resulted in the redistribution and reorientation of the infiltrated clays forming a pervasive I/Sm coatings around the detrital grains. This process followed the shallow dissolution in pay zone 1 and the glauconite authigenesis in pay zone 2 sandstones (Fig. 13). I/Sm coatings in the deeper pay zone 2 sandstones likely promoted the mechanical compaction which allowed the development of mild quartz overgrowth (Tournier et al. 2010). Quartz overgrowth only characterizes the pay zone 2 sandstones (Av. 0.6\%), and its onset likely occurred in the very recent times (Pleistocene) when the burial temperature exceeded $65^{\circ} \mathrm{C}$ (Fig. 13; e.g., Loucks et al. 1984; Kim et al. 2007; Leila et al. 2019). However, the content of quartz overgrowth is still very low. and its impact on the pay zone 2 reservoir quality is negligible. Accordingly, the shallow burial of both pay zones with burial temperatures never exceeded $65{ }^{\circ} \mathrm{C}$ (Fig. 13) results in development of only minor authigenic phases that virtually did not impact these reservoir characteristics. Consequently, the depositional and early burial attributes are the main factor controlling the reservoir quality of the studied Pliocene pay zones (Fig. 13).

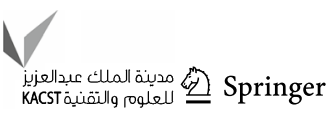




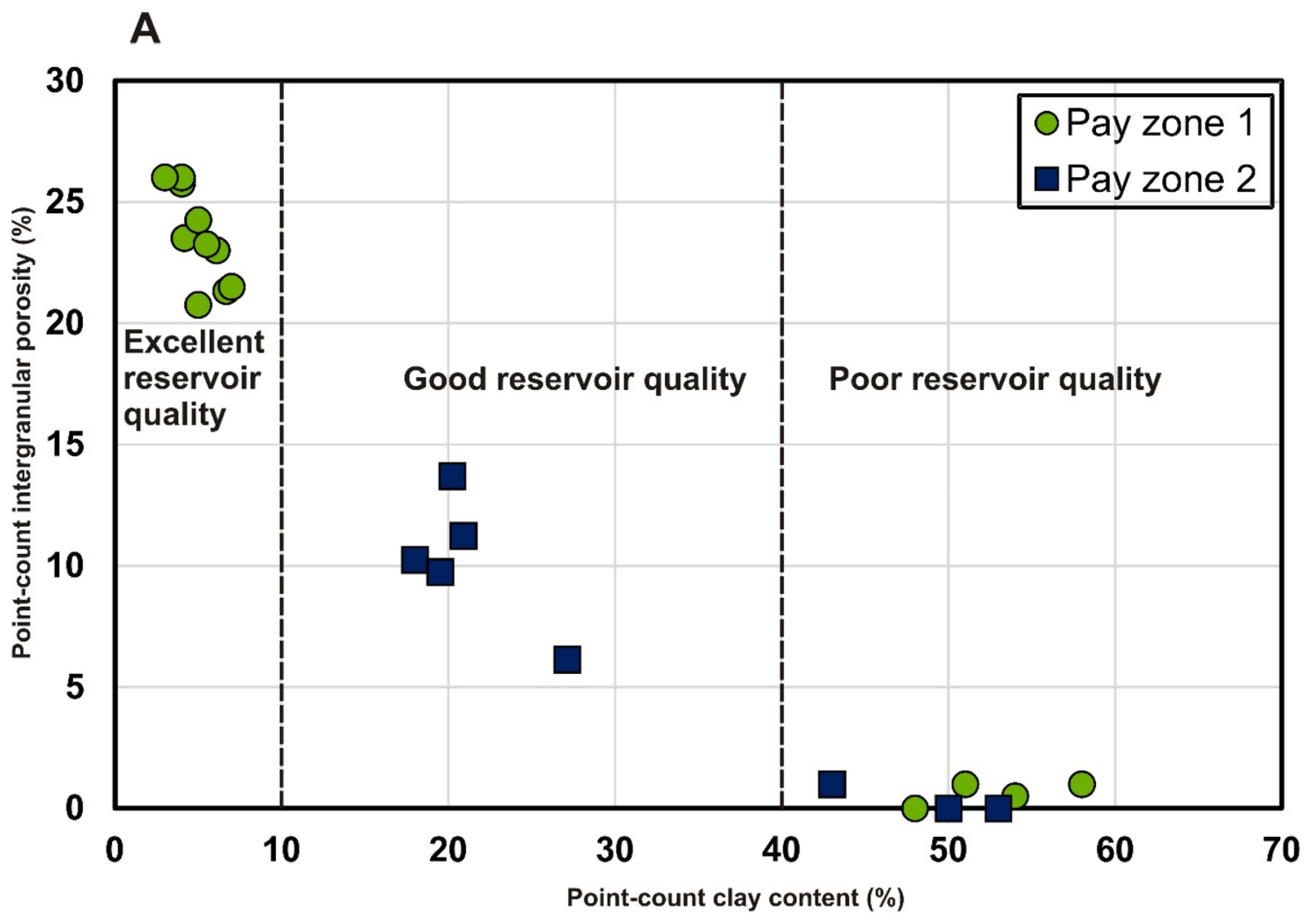

B

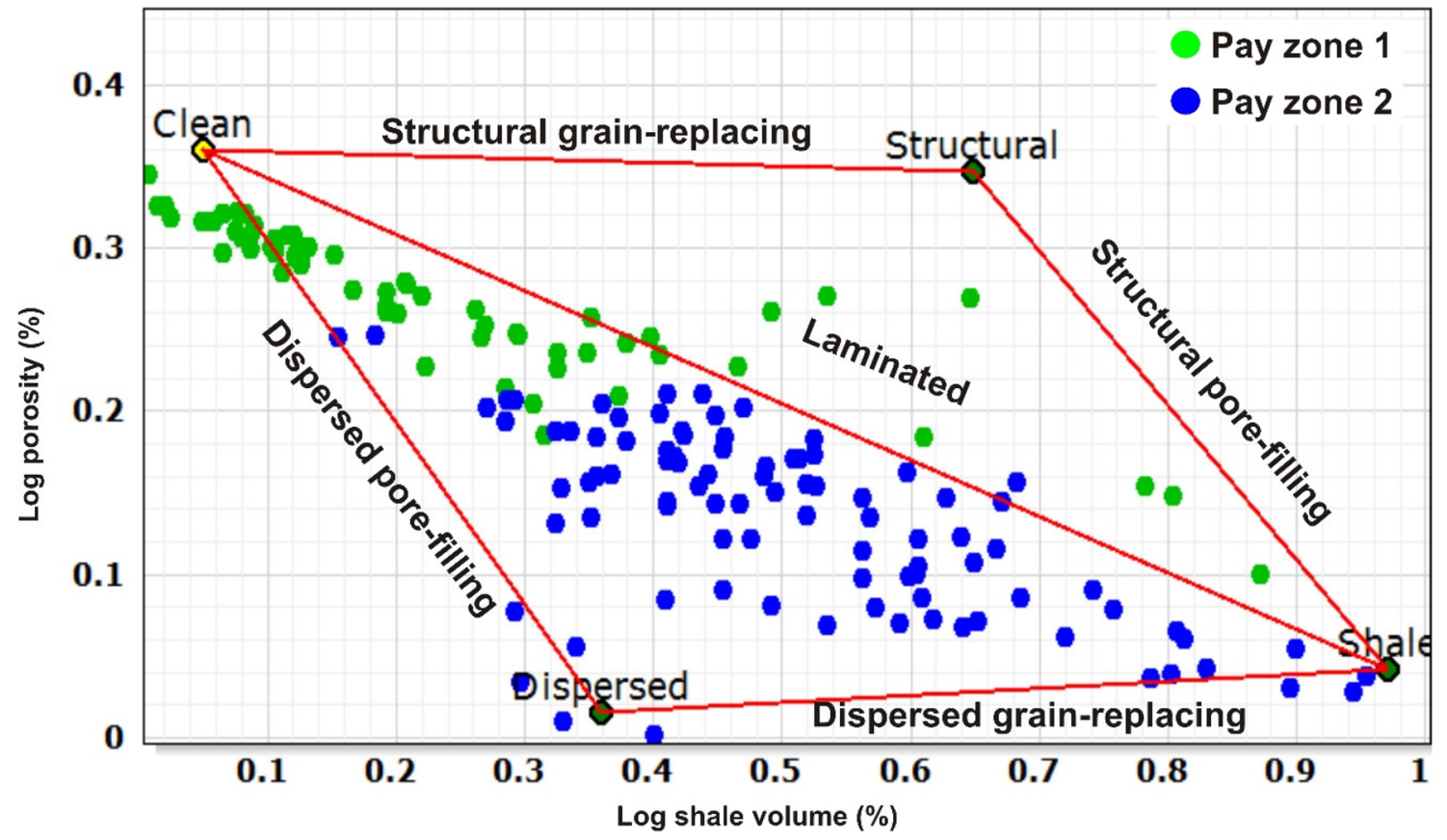

Fig. 11 Point-count and log-derived porosity and clay content cross-plots revealing the enormous impact of clay content on the reservoir quality of the studied Pliocene sandstones 

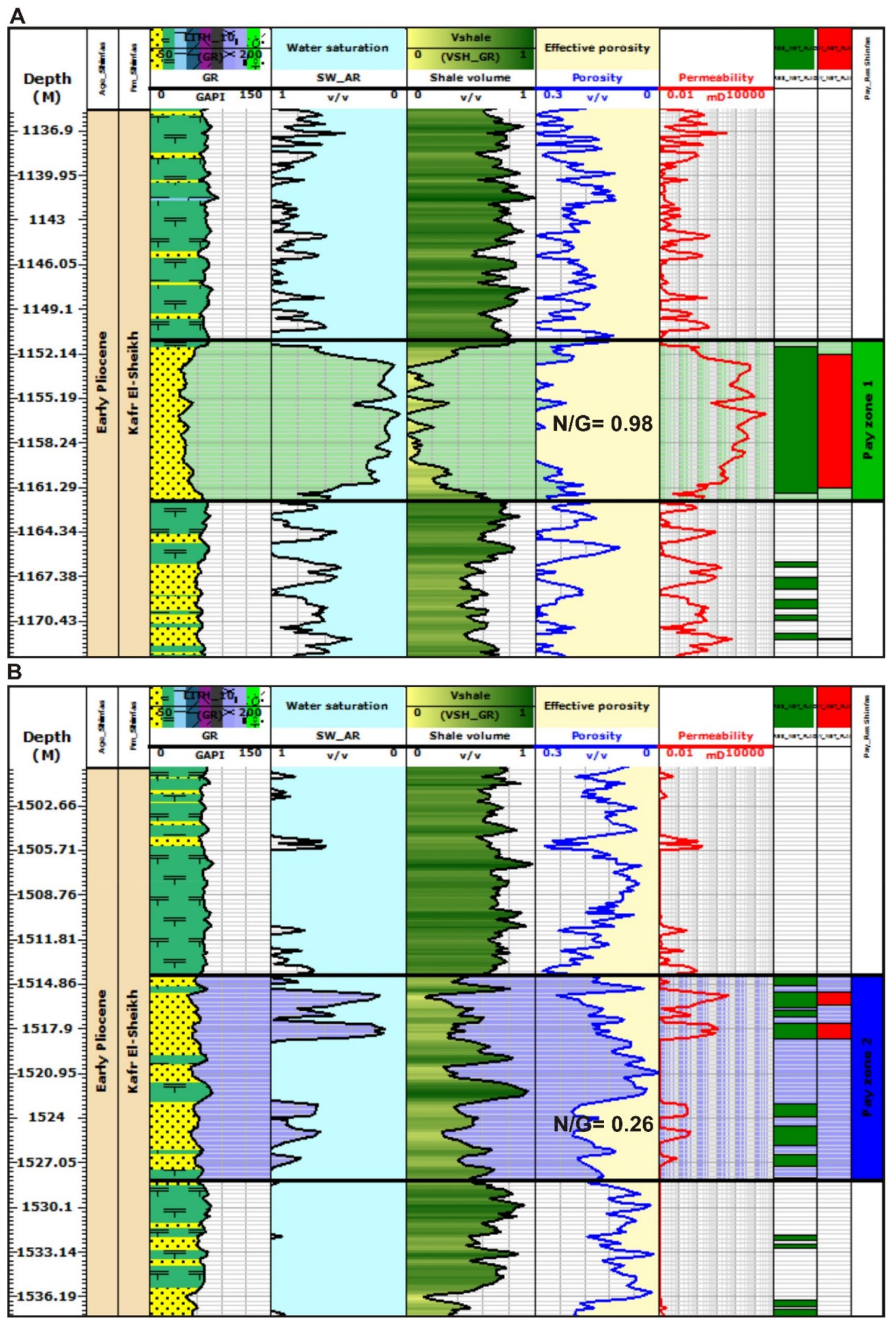

Fig. 12 Vertical distribution of log-derived petrophysical characteristics within the studied pay zones confirming the better reservoir quality of pay zone 1 (a) than pay zone 2 sandstones (b) 


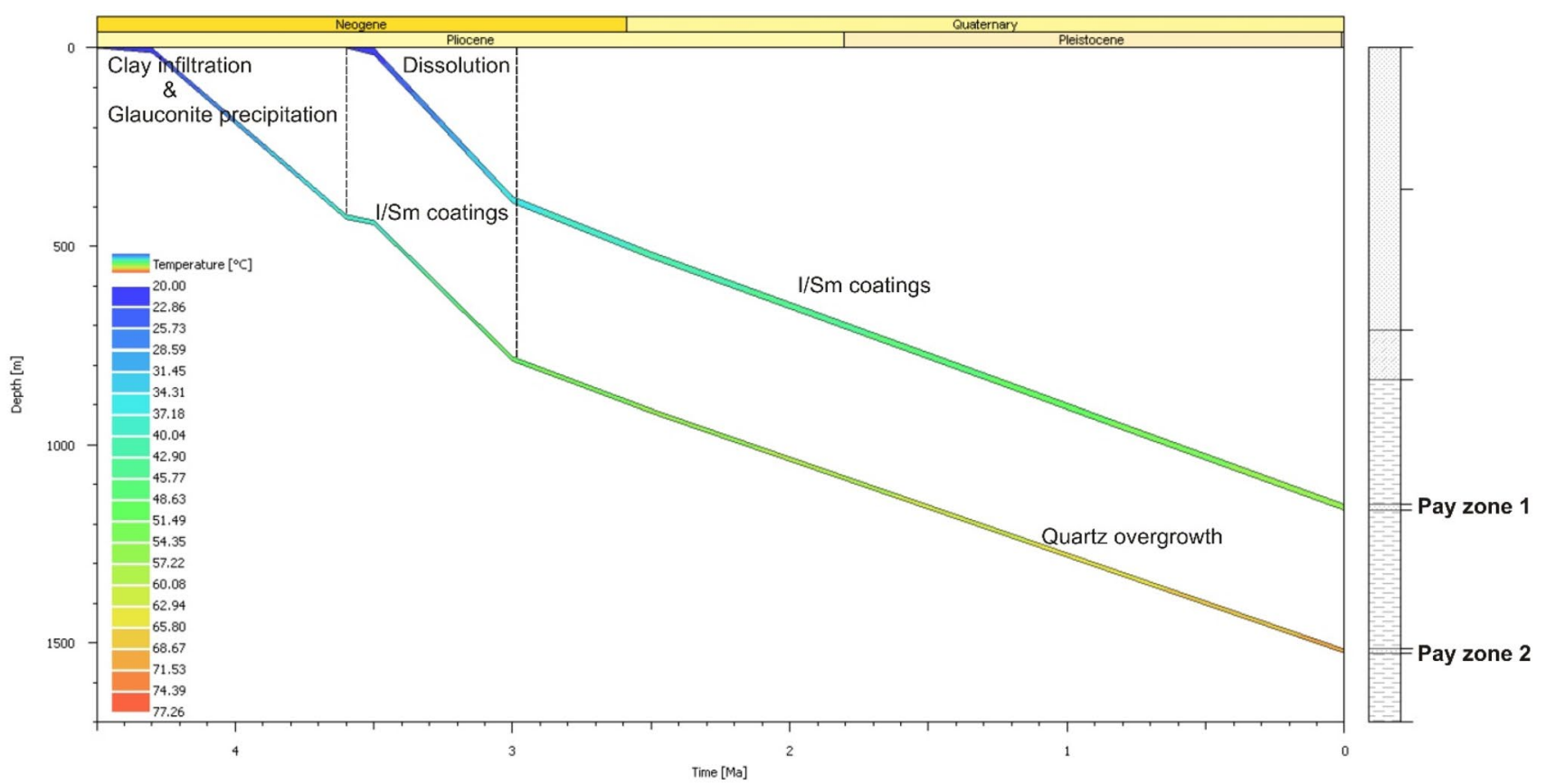

Fig. 13 Burial history diagram of the studied pay zones demonstrating the paragenetic sequence of the different diagenetic phases. Both pay zones were subjected to low burial temperatures resulting in authigenesis of minor diagenetic phases

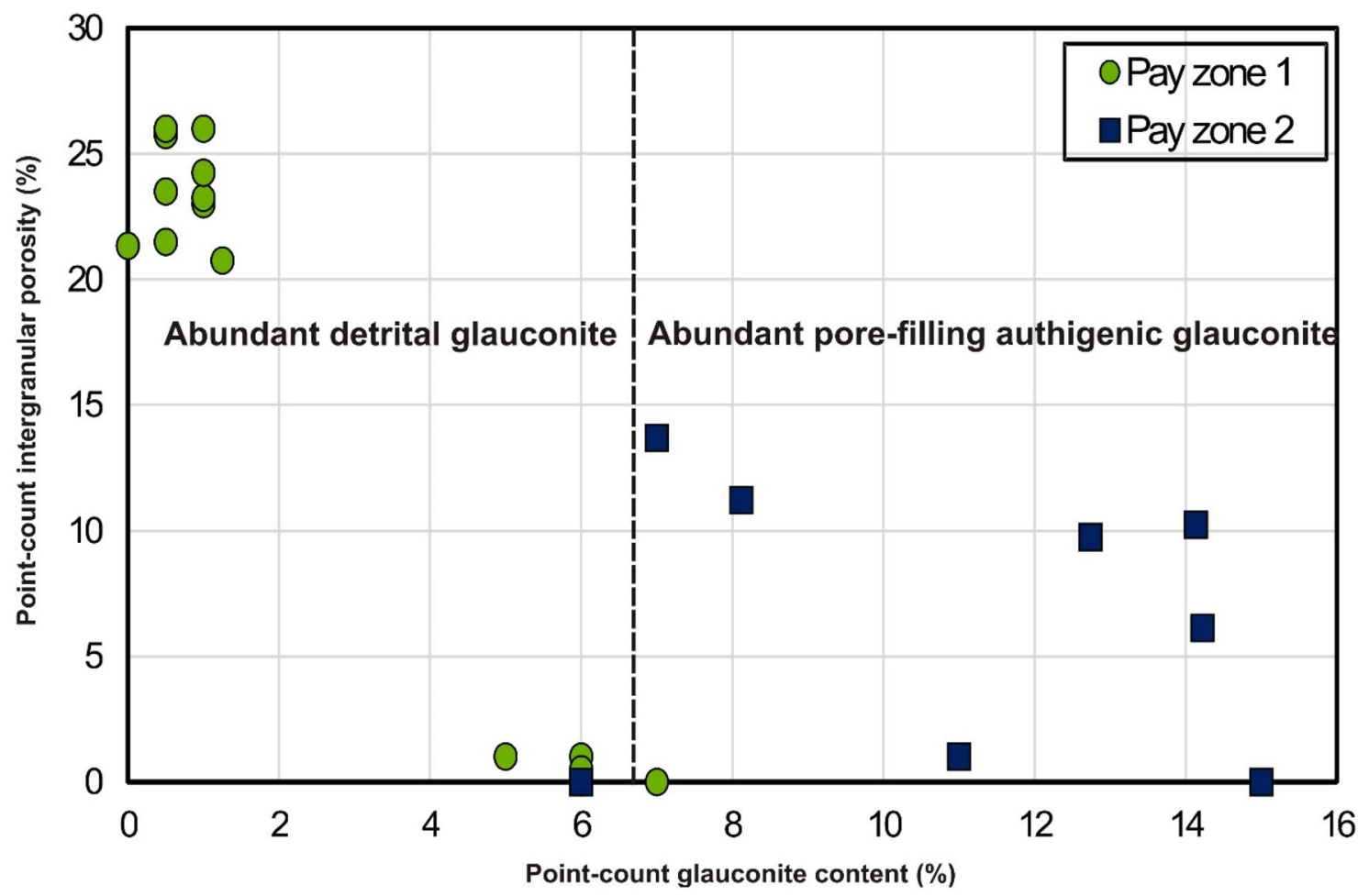

Fig. 14 Point-count porosity versus glauconite content cross-plot demonstrating the comparatively elevated detrimental impact of glauconite on the reservoir quality of pay zone 2 sandstones 

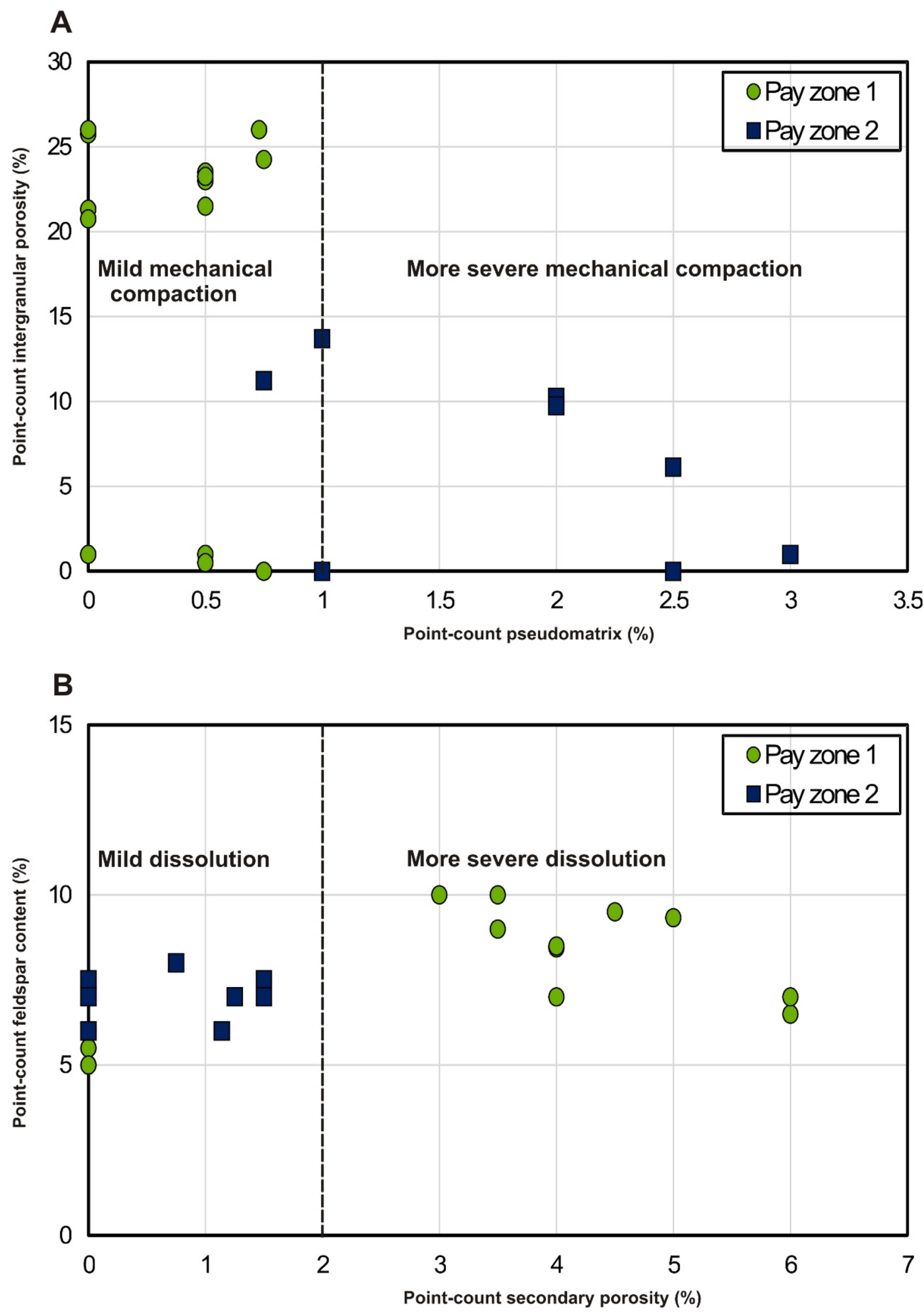

Fig. 15 Point-count data cross-plots illustrating the differential impacts of both mechanical compaction (a) and dissolution (b) on the studied pay zones reservoir quality 


\section{Conclusions}

- The studied Pliocene pay zones have similar detrital composition dominated by subarkose arenite and arkosic wacke sandstones.

- Pay zone 1 consists of NW-SE and NE-SW-oriented distributary channel-fill sandstones, whereas pay zone 2 comprises the $\mathrm{N}-\mathrm{S}$ isolated transgressive distal sand bars.

- The studied pay zones were subjected to mild diagenetic modifications which were mainly controlled by their initial depositional conditions.

- Pervasive eodiagenetic infiltration of clays (Av. 31\%) and precipitation of authigenic glauconite (Av. 7\%) in the pay zone 2 sandstones have the most detrimental impact on their reservoir quality.

- Enhanced mechanical compaction over pay zone 2 sandstones resulted in formation of pseudomatrix materials reducing the primary intergranular porosity.

- Extensive meteoric water incursion in pay zone 1 sandstones enhanced their reservoir characteristics by pervasive dissolution of feldspars and neoformation of secondary porosity (Av. 2.9\%).

- Pay zone 1 hosts a thicker gas accumulation $(\mathrm{N} / \mathrm{G}=0.98)$, whereas the reservoir heterogeneity of pay zone 2 caused the presence of only residual gases $(\mathrm{N} / \mathrm{G}=0.26)$.

- The depositional (e.g., matrix composition and content) and eodiagenetic attributes (glauconitization and clay infiltration) are the key factor controlling the reservoir quality of the studied Pliocene pay zones.

- The present study clarifies the differential impact of the early diagenetic attributes on the reservoir quality of the shallow siliciclastic reservoirs deposited in different depositional settings.

Acknowledgements The authors wish to thank the Egyptian General Petroleum Corporation (EGPC) and Mansoura Petroleum Company, Egypt, for providing the data and materials that were necessary for the completion of this research. We are also grateful to Schlumberger for granting access to academic license of the Petrel and Techlog software.

Open Access This article is licensed under a Creative Commons Attribution 4.0 International License, which permits use, sharing, adaptation, distribution and reproduction in any medium or format, as long as you give appropriate credit to the original author(s) and the source, provide a link to the Creative Commons licence, and indicate if changes were made. The images or other third party material in this article are included in the article's Creative Commons licence, unless indicated otherwise in a credit line to the material. If material is not included in the article's Creative Commons licence and your intended use is not permitted by statutory regulation or exceeds the permitted use, you will need to obtain permission directly from the copyright holder. To view a copy of this licence, visit http://creativecommons.org/licenses/by/4.0/.

\section{References}

Abd-Allah AMA (2008) Mesozoic-Cenozoic inversion tectonic of North Sinai: integration of structural and basin analysis. J Appl Geophys 7:77-108

Abdel Aal A, Price R, Vital J, Sharallow J (1994) Tectonic evolution of the Nile delta, its impact on sedimentation and hydrocarbon potential. In: Proceedings on 12th EGPC exploration and production conference, Cairo, Egypt, vol 1, pp 19-34

Amorosi A (1995) Glaucony and sequence stratigraphy: a conceptual framework of distribution in siliciclastic sequences. J Sediment Res B65:419-425

Amorosi A, Centineo MC (1997) Glaucony from the Eocene of the Isle of Wight (southern UK): implications for basin analysis. Geol Soc Lond J 154:887-896

Barber P (1981) Messinian subaerial erosion of the proto-Nile Delta. Mar Geol 44:253-272

Blatt H, Tracy R (1996) Petrology: igneous, sedimentary, and metamorphic, 2nd edn. Freeman, New York City, p 518

Clauzon G, Rubino J, Savoye B (1995) Marine Pliocene Gilbert-type fan deltas along the French Mediterranean coast. Atypical infill feature of preexisting subaerial Messinian canyons. In: IAS Reg. Met. Sed., Field trip Guide book. Publ., A.S.F, vol 23, pp 145-222

Corex (2007) Sedimentological and petrographic analyses on the cored Abu Madi Formation from West Al-Khilala Field wells, Nile Delta, Egypt. (unpublished internal reports)

Dalla S, Hamed H, Serrazi M (1997) Hydrocarbon exploration in a complex incised valley fill: An example from the late Messinian Abu Madi Formation (Nile Delta Basin, Egypt). Lead Edge 16(12):1819-1824. https://doi.org/10.1190/1.1437590

Dean E, Stark D (1920) A convenient method for the determination of water in petroleum and other organic emulsions. J Ind Eng Chem 12:486-490

Dickinson W (1970) Interpreting detrital modes of greywacke and arkose. J Sediment Petrol 40:695-707

Dixon JE, Robertson AHF (1984) The geological evolution of the Eastern Mediterranean. Geol Soc Lond Special Publ 17:844

Dolson C, Shaan V, Matbouly S, Harwood C, Rashed R, Hammouda H (2001) The petroleum potential of Egypt. In: Downey W, Threet C, Morgan A.(eds) Petroleum provinces of the twenty-first century, vol 74. AAPG, pp 453-482

Dolson JC, Boucher PJ, Siok J, Heppard P (2005) Key challenges to realizing full potential in an emerging giant gas province: Nile Delta/Mediterranean offshore, deep water, Egypt. In: Doré AG, Vining BA (eds) Petroleum geology: North-West Europe and global perspectives, Geological Society, London, petroleum geology conference series no. 6 , proceedings on 6th petroleum geology conference, pp 607-624

EGPC (Egyptian General Petroleum Corporation) (1994) Nile Delta and North Sinai: field discoveries and hydrocarbon potentials (a comprehensive overview). EGPC, Cairo, p 387

Garcia-castellanos D, Estrada F, Jiménez-munt I, Gorini C, Fernàndez M, Vergés J, De Vicente R (2009) Catastrophic flood of the Mediterranean after the Messinian salinity crisis. Nature 462:778-781

Gazzi P (1966) Le arenaire del fl-ysch sopracretaceo dell'Appennino modenses: Correlazioni con il flysch di monghidoro. Mineral Petrogr Acta 12:69-97

Hammer E, Mørk M, Naess A (2010) Facies controls on the diagenesis and compaction in fluvial-deltaic deposits. Mar Petrol Geol 27:1737-1751

Harms J, Wray J (1990) Nile Delta. In: Said R (ed) The geology of Egypt. Balkema, Rotterdam, pp 329-344

Higgs K, Zwingmann H, Reyes A, Funnell R (2007) Diagenesis, porosity evolution, and petroleum emplacement in tight gas reservoirs, Taranaki Basin, New Zealand. J Sedmint Res 77:1003-1025 
Hussein IM, Abd-Allah AMA (2001) Tectonic evolution of the northeastern part of the African continental margin, Egypt. J Afr Earth Sci 33:49-69

Kamel H, Eita T, Sarhan M (1998) Nile delta hydrocarbon potentiality, Egypt. In: Proceedings on 14th EGPC exploration and production conference, Cairo, Egypt, vol 1, pp 485-503

Kim J, Yong L, Hisada K (2007) Depositional and compositional controls on sandstone diagenesis, the Tetori Group (Middle JurassicEarly Cretaceous), central Japan. Sedmint Geol 195:183-202

Leila M (2019) Clay minerals distribution in the pre-, syn-Messinian salinity crisis sediments of the onshore Nile Delta, Egypt: Mineral origin and implications on the reservoir quality. J Afr Earth Sci 154:35-48

Leila M, Moscariello A (2017) Organic geochemistry of oil and natural gas in the West Dikirnis and El-Tamad fields onshore Nile Delta, Egypt: interpretation of potential source rocks. J Petrol Geol 40:37-58

Leila M, Moscariello A (2018) Depositional and petrophysical controls on the volumes of hydrocarbons trapped in the Messinian reservoirs, onshore Nile Delta, Egypt. Petroleum 4:250-267

Leila M, Moscariello A (2019) Seismic stratigraphy and sedimentary facies analysis of the pre- and syn-Messinain salinity crisis sequences, onshore Nile Delta, Egypt: implications for reservoir quality prediction. Mar Petrol Geol 101:303-321

Leila M, Kora M, Ahmed M, Ghanem A (2015) Sedimentology and reservoir characterization of the Upper Miocene Qawasim Formation, El-Tamad oil Field onshore Nile Delta, Egypt. Arab J Geosci 9:1-13

Leila M, Moscariello A, Šegvić B (2019) Depositional facies controls on the diagenesis and reservoir quality of the Messinian Qawasim and Abu Madi formations, onshore Nile Delta, Egypt. Geol J 54:1797-1813

Lofi J, Gorini C, Berne S, Clauzon G, Dos Reis A, Ryan W, Steckler M (2005) Erosional processes and paleo-environmental changes in the Western Gulf of Lions (SW France) during the Messinian Salinity Crisis. Mar Geol 217:1-30

Loncke L, Gaullier V, Bellaiche G, Mascle J (2002) Recent depositional patterns of the Nile deep-sea fan from echo-character mapping. AAPG Bull 86:1165-1186

Loucks R, Dodge M, Galloway W (1984) Regional controls on diagenesis and reservoir quality in lower Tertiary sandstones along the Texas Gulf Coast. In: McDonald D, Surdam R (eds) Clastic diagenesis. AAPG Memoir, Tulsa

Loutit T, Allard D, Dolson J, Schruers J, Laura S (2001) A new view of Egypt's hydrocarbon potential. In: Proceedings on Middle East and North Africa (MENA) conference, London, pp 350

Lundergard P (1991) Sandstone porosity loss—a "Big Picture" view of the importance of compaction. J Sediment Res 62:250-260

Mansurbeg H (2017) The use of diagenetic signatures to distinguish marine from continental deposits in Triassic-Jurassic sandstone reservoirs from the UK Central Graben. Mar Petrol Geol 79:188-200

Michalopoulos P, Aller RC (1995) Rapid clay mineral formation in Amazon delta sediments: reverse weathering and oceanic elemental cycles. Science 270:614-617

Morad S, Ketzer J, De Ros L (2000) Spatial and temporal distribution of diagenetic alterations in siliciclastic rocks: implications for mass transfer in sedimentary basins. Sedimentology 47:95-120

Mosconi A, Rebora A, Venturino G, Bocc P, Khalil MH (1996) EgyptNile Delta and North Sinai Cenozoic tectonic evolutionary model: a proposal. In: Proceedings on 13th EGPC exploration and production conference, Cairo, Egypt, pp 203-123

Odin G, Fullagar P (1988) Geological significance of the glaucony facies. In: Odin G (ed) Green marine clays, developments in sedimentology, vol 45. Elsevier, Amsterdam, pp 295-332
Odin G, Matter A (1981) De glauconiarum origine. Sedimentology 28:611-641

Orwig E (1982) Tectonic framework of northern Egypt and the eastern Mediterranean regime. In: EGPC 6th exploration seminar, Egypt, $20 \mathrm{pp}$

Palmieri G, Harby H, Martini J, Hashem F, Dalla S, Shash M (1996) Baltim Fields complex: an outstanding example of hydrocarbon accumulations in a fluvial Messinian incised valley. In: Proceedings on 13th EGPC exploration and production conference, Cairo, Egypt, vol 1, pp 256-269

Ramm M (1992) Porosity-depth trends in reservoir sandstones: offshore Norway. Mar Petrol Geol 9:553-567

Riad S, Abdelrahman E, Refai E, El-Ghalban H (1989) Geothermal studied in the Nile Delta. J Afr Earth Sci 9:637-649

Rizzini A, Vezzani F, Coccocetta V, Milad G (1978) Stratigraphy and Sedimentation of Neogene-Quaternary section in the Nile Delta area, (A.R.E). Mar Geol 27:327-348

Ross D, Uchupi E (1977) Structure and sedimentary history of northeastern Mediterranean Sea-Nile cone area. AAPG Bull 61:872-902

Said R (1990) The geology of Egypt. A. Balkema Publishers, New York, $\mathrm{p} 734$

Sallam E, Issawi B, Osman R, Ruban D (2018) Deposition in a changing paleogulf: evidence from the Pliocene-Quaternary sedimentary succession of the Nile Delta, Egypt. Arab J Geosci 11:558

Samuel A, Kneller B, Raslan S, Sharp A, Parsons C (2003) Prolific deep-marine slope channels of the Nile Delta, Egypt. AAPG Bull 87:541-560

Sarhan M, Hemdan K (1994) North Nile Delta structural setting trapping and mechanism, Egypt. In: Proceedings on 14th EGPC exploration and production conference, Cairo, Egypt, vol 1, pp $1-18$

Schön JH (1996) Physical properties of rocks: fundamentals and principles of petrophysics. Elsevier, Oxford, p 582

Shaaban F, Lutz R, Littke R, Bueker C, Odisho K (2006) Source rock evaluation and basin modeling in the NE Egypt (NE Nile Delta and Northern Sinai). J Petrol Geol 29:103-124

Surdam R, Boese S, Crossey L (1984) The chemistry of the secondary porosity. In: Surdam R, McDonald D (eds) Clastic diagenesis, AAPG Bulleetin, vol 37, pp 127-149

Tournier F, Pagel M, Portier E, Wazir E, Fiet N (2010) Relationship between deep diagenetic quartz cementation and sedimentary facies in a Late Ordovician glacial environment (Sbaa basin, Algeria). J Sediment Res 80:1068-1084

Vandre C, Cramer B, Gerling P, Winsemann J (2007) Natural gas formation in the western Nile Delta (Eastern Mediterranean): thermogenic versus microbial mechanisms. Org Geochem 38:523-539

Worden R, Morad S (2003) Clay minerals in sandstones: controls on formation, distribution and evaluation. Spec Publ Int Assoc Sedmint 34:3-41

Worthington PF (1985) The evolution of shaly-sand concepts in reservoir evaluation. Log Anal 23(1):23-40

Yuan G, Cao Y, Zhang Y, Gluyas J (2017) Diagenesis and reservoir quality of sandstones with ancient "Deep" incursion of meteoric freshwater-an example in the Nanpu Sag, Bohai Bay Basin, East China. Mar. Petrol. Geol. 82:444-464

Zachos J, Pagani M, Sloan L, Thomas E, Billups K (2001) Trends, rhythms, and aberrations in global climate $65 \mathrm{Ma}$ to present. Science 292:686-693

Publisher's Note Springer Nature remains neutral with regard to jurisdictional claims in published maps and institutional affiliations. 